University of Nebraska - Lincoln

DigitalCommons@University of Nebraska - Lincoln

$4-12-2008$

\title{
Transport and Fate of Nitrate at the Ground-Water/Surface-Water Interface
}

Larry J. Puckett

USGS

Celia Zamora

USGS

Hedeff Essaid

USGS

John T. Wilson

USGS

Henry M. Johnson

USGS, hjohnson@usgs.gov

See next page for additional authors

Follow this and additional works at: https://digitalcommons.unl.edu/usgsstaffpub

Part of the Earth Sciences Commons

Puckett, Larry J.; Zamora, Celia; Essaid, Hedeff; Wilson, John T.; Johnson, Henry M.; Brayton, Michael; and Vogel, Jason R., "Transport and Fate of Nitrate at the Ground-Water/Surface-Water Interface" (2008). USGS Staff -- Published Research. 4.

https://digitalcommons.unl.edu/usgsstaffpub/4

This Article is brought to you for free and open access by the US Geological Survey at DigitalCommons@University of Nebraska - Lincoln. It has been accepted for inclusion in USGS Staff -- Published Research by an authorized administrator of DigitalCommons@University of Nebraska - Lincoln. 


\section{Authors}

Larry J. Puckett, Celia Zamora, Hedeff Essaid, John T. Wilson, Henry M. Johnson, Michael Brayton, and Jason R. Vogel 


\title{
Transport and Fate of Nitrate at the Ground-Water/Surface-Water Interface
}

\author{
Larry J. Puckett, * Celia Zamora, Hedeff Essaid, John T. Wilson, Henry M. Johnson, Michael J. Brayton, and Jason R. Vogel USGS
}

Although numerous studies of hyporheic exchange and denitrification have been conducted in pristine, high-gradient streams, few studies of this type have been conducted in nutrientrich, low-gradient streams. This is a particularly important subject given the interest in nitrogen $(\mathrm{N})$ inputs to the Gulf of Mexico and other eutrophic aquatic systems. A combination of hydrologic, mineralogical, chemical, dissolved gas, and isotopic data were used to determine the processes controlling transport and fate of $\mathrm{NO}_{3}{ }^{-}$in streambeds at five sites across the USA. Water samples were collected from streambeds at depths ranging from 0.3 to $3 \mathrm{~m}$ at three to five points across the stream and in two to five separate transects. Residence times of water ranging from 0.28 to $34.7 \mathrm{~d} \mathrm{~m}^{-1}$ in the streambeds of $\mathrm{N}$-rich watersheds played an important role in allowing denitrification to decrease $\mathrm{NO}_{3}^{-}$concentrations. Where potential electron donors were limited and residence times were short, denitrification was limited. Consequently, in spite of reducing conditions at some sites, $\mathrm{NO}_{3}{ }^{-}$was transported into the stream. At two of the five study sites, $\mathrm{NO}_{3}{ }^{-}$in surface water infiltrated the streambeds and concentrations decreased, supporting current models that $\mathrm{NO}_{3}{ }^{-}$would be retained in $\mathrm{N}$-rich streams. At the other three study sites, hydrogeologic controls limited or prevented infiltration of surface water into the streambed, and ground-water discharge contributed to $\mathrm{NO}_{3}^{-}$loads. Our results also show that in these low hydrologic-gradient systems, storm and other high-flow events can be important factors for increasing surface-water movement into streambeds.

Copyright $\odot 2008$ by the American Society of Agronomy, Crop Science Society of America, and Soil Science Society of America. All rights reserved. No part of this periodical may be reproduced or transmitted in any form or by any means, electronic or mechanical, including photocopying, recording, or any information storage and retrieval system, without permission in writing from the publisher.

Published in J. Environ. Qual. 37:1034-1050 (2008). doi:10.2134/jeq2006.0550

Received 20 Dec. 2006.

*Corresponding author (lpuckett@usgs.gov).

(c) ASA, CSSA, SSSA

677 S. Segoe Rd., Madison, WI 53711 USA
$\mathrm{M}$ OST studies of nitrogen $(\mathrm{N})$ cycling at the ground-water/ surface-water interface have focused on hyporheic zone processes in relatively pristine $\mathrm{N}$-limited streams (e.g., Duff and Triska, 1990; Triska et al., 1990, 1993; Holmes et al., 1996; Wondzell and Swanson, 1996; Duff and Triska, 2000). Typically in these settings, biogeochemical processes in the hyporheic zone produce $\mathrm{NH}_{4}^{+}$or $\mathrm{NO}_{3}{ }^{-}$through $\mathrm{NO}_{3}^{-}$reduction, ammonification, and nitrification. In the context of these studies, the hyporheic zone has been seen as an $\mathrm{N}$ source to surface waters. In contrast, information on $\mathrm{N}$ transport and fate in hyporheic zones of $\mathrm{N}$-enriched streams in intensive agricultural settings is limited. Pinay et al. (1994) documented a net loss of $\mathrm{NO}_{3}^{-}$ due to denitrification as surface water infiltrated a gravel bar of the Garonne River, France. McMahon and Böhlke (1996) reported a net decrease in $\mathrm{NO}_{3}{ }^{-}$concentrations in the South Platte River, $\mathrm{CO}$, as a result of denitrification in the riparian and hyporheic zones. Hill et al. (1998) reported that the hyporheic zone of a small $\mathrm{N}$-rich stream in Ontario served as a $\mathrm{NO}_{3}^{-}$sink, and Hinkle et al. (2001) reported $\mathrm{NO}_{3}{ }^{-}$removals from discharging ground water in the hyporheic zone of the Willamette River in Oregon. Storey et al. (2004) reported streambed denitrification in a moderately $\mathrm{N}$-rich stream in southern Ontario. More recently, Opdyke et al. (2006) and Royer et al. (2004; 2006) found that stream discharge of $\mathrm{NO}_{3}{ }^{-}$in areas having extensive tile drains so exceeded denitrification capacity that it was not an efficient $\mathrm{NO}_{3}{ }^{-}$sink. Thus, the latter notwithstanding, available evidence supports the conceptual model hypothesized by Jones and Holmes (1996) that hyporheic zones in $\mathrm{NO}_{3}{ }^{-}$-rich streams may act as $\mathrm{NO}_{3}{ }^{-}$sinks, whereas in $\mathrm{NO}_{3}{ }^{-}$-poor streams they are $\mathrm{NO}_{3}{ }^{-}$sources.

Conversely, there is ample evidence in the literature that riparian zones may serve as sinks for $\mathrm{NO}_{3}{ }^{-}$in ground water before it reaches surface-water bodies (e.g., Haycock et al., 1993; Hill, 1996; Puckett, 2004). It has also become increasingly clear that hydrogeologic and biogeochemical processes may limit denitrification; therefore, not all riparian zones are equally efficient at removing $\mathrm{NO}_{3}{ }^{-}$from ground water before it reaches stream channels (e.g., Hill, 1996; Puckett et al., 2002; Puckett, 2004; Puckett and Hughes, 2005). Because the predominant focus of hyporheic zone studies has been on interactions with stream water, there is little information on whether hyporheic zones serve as a source or a sink with respect to $\mathrm{NO}_{3}{ }^{-}$in ground water discharging to streams. This raises the question whether hyporheic zones are capable of removing $\mathrm{NO}_{3}{ }^{-}$in ground water discharging to

L.J. Puckett, USGS, 413 National Center, Reston, VA 20192; C. Zamora, USGS, 6000 J Street, Sacramento, CA 95819; Hedeff Essaid, USGS, 345 Middlefield Road, Menlo Park, CA 94205; J.T. Wilson, USGS, 5957 Lakeside Boulevard, Indianapolis, IN 46278; H.M. Johnson, USGS, 10615 SE Cherry Blossom Drive, Portland, OR 97216; M.J. Brayton, USGS, 8987 Yellow Brick Road, Baltimore, MD 21237; and J.R. Vogel, USGS, 5231 S. 19th Street, Lincoln, NE 68512.

Abbreviations: $\mathrm{DOC}$, dissolved organic carbon; DNRA, dissimilatory $\mathrm{NO}_{3}^{-}$reduction; PVC, polyvinyl chloride. 
the streambed before entering the stream itself, therefore serving as an added bioremediation barrier to surface-water contamination.

The potential importance of streambed permeability as a control on hyporheic exchanges has been recognized by several authors (Triska et al., 1989; Vervier et al., 1992; Triska et al., 1993; Valett et al., 1996). Jones and Holmes (1996) suggested expanding the scope of such studies to include the roles of hydraulic conductivity and hydraulic gradients as incorporated in Darcy's Law. Little research has been conducted on the relationship between the physical properties of the bed sediments and their control on ground-water/surface-water interactions in streambeds.

In this study, we investigated the transport and fate of $\mathrm{NO}_{3}^{-}$ within the ground-water/surface-water interface at five study sites across the USA: DR2 Drain, Washington; Merced River, California; Maple Creek, Nebraska; Leary Weber Ditch, Indiana; and Morgan Creek, Maryland. At all sites the same study design, schedule of analytes, and methods were used to facilitate comparison of results. This analysis included characterization of the redox state of ground-water and hyporheic zone samples, solidphase electron donors (organic carbon, $\mathrm{Fe}^{2+}, \mathrm{S}^{2-}$ ), dissolved gases, isotopes, and intensive monitoring of ground-water/surface-water hydrology. All of these sites are in intensive agricultural watersheds having elevated $\mathrm{N}$ concentrations (relative to background values defined by Fuhrer et al., 1999) in ground water, surface water, or both (Domagalski et al., 2008; Green et al., 2008).

Our main objective was to examine the processes controlling transport and fate of $\mathrm{NO}_{3}{ }^{-}$in discharging ground water as it passed through the streambed. Because it is possible for the ground water to move through the streambed faster than processes controlling $\mathrm{NO}_{3}{ }^{-}$transport and fate, a particular focus of this study was investigating the role of flow rates and water residence times on $\mathrm{NO}_{3}{ }^{-}$removal. Accordingly, our primary hypothesis was that hydrogeology expressed in the form of hydraulic conductivity, porosity, and hydraulic gradient would control the direction and rate of flow of ground water and surface water in the streambed and that this in turn would influence $\mathrm{NO}_{3}{ }^{-}$retention. A second objective was to investigate $\mathrm{NO}_{3}{ }^{-}$removal in $\mathrm{N}$-enriched agro-ecosystems in a variety of hydrogeologic settings across the USA with the hypothesis that these systems would retain $\mathrm{NO}_{3}{ }^{-}$.

\section{Site Descriptions}

\section{DR2 Drain, Washington}

More extensive site descriptions along with maps and tables of additional watershed characteristics for each study site are provided by Capel et al. (2008). The $5.5-\mathrm{km}^{2}$ DR2 Drain study site is located in Yakima County in south-central Washington. At the time of the study, approximately $88 \%$ of the area was cropland that included corn (Zea mays L.), row crops, orchards, vineyards, and dairies; total $\mathrm{N}$ use for the DR2 watershed during 2004 was estimated as $62 \mathrm{Mg}$ (Payne et al., 2007) or about $128 \mathrm{~kg} \mathrm{ha}^{-1}$. The upper 3 to $10 \mathrm{~m}$ of aquifer material are silty sands and clayey silts deposited by the draining of glacial Lake Missoula (Waitt, 1984). In addition to 15 to $20 \mathrm{~cm}$ of precipitation, 75 to $120 \mathrm{~cm}$ of irrigation water is applied to cropland between April and September. Water within the DR2 Drain comprises shallow ground water, deeper ground water, and relatively dilute irrigation water.

Drains and ditches are artificial channels used to remove excess water in agricultural areas. Within the lower part of the basin, which was the focus of this investigation, ground-water discharges result in perennial flow in the drain. The bed of DR2 Drain consists of the same silty sands and clayey silts as those in the aquifer, having vertical hydraulic conductivities estimated at $1.295 \times 10^{-6}$ to $1.295 \times 10^{-5} \mathrm{~m} \mathrm{~s}^{-1}$ (Essaid et al., 2008). The channel is about $3 \mathrm{~m}$ wide, is periodically dredged, and has a surface-water gradient of 0.004 . A dairy feedlot is on the left bank, and irrigated pasture is on the right bank along the 150-m-long study reach of DR2 Drain.

\section{Merced River, California}

The $832-\mathrm{km}^{2}$ lower Merced River basin is in the eastern San Joaquin Valley, California. Land use in the study area is mostly agriculture, with narrow strips of riparian vegetation along the river. The dominant crops are orchards and vineyards, followed by field crops, pasture, and truck crops; $\mathrm{N}$ use in 2004 was estimated at $7300 \mathrm{Mg}$ (Gronberg and Kratzer, 2006) or about $160 \mathrm{~kg} \mathrm{ha}^{-1}$. Alluvial deposits derived from the Sierra Nevada Mountains to the east underlie the land surface. Crops are irrigated with surface water from the Sierra Nevada Mountains; some crops south of the Merced River are irrigated with water pumped from the river. Discharge of the lower Merced River is mostly controlled through management of a major upstream reservoir. Ground-water flow in the study area generally is toward the Merced River, where most of the ground-water discharge occurs. The riverbed consists of coarse sand and gravel alluvial deposits, with vertical hydraulic conductivities estimated at $1.2 \times 10^{-5}$ to $1.2 \times 10^{-4} \mathrm{~m} \mathrm{~s}^{-1}$ (Essaid et al., 2008). The channel is about $30 \mathrm{~m}$ wide and has a negligible surface-water gradient. Within the 200-m-long study reach, in 2004 there was a large vineyard on the left bank and a narrow riparian strip, corn field, and orchards on the right bank.

\section{Maple Creek, Nebraska}

Maple Creek, a tributary to the Elkhorn River in eastern Nebraska, drains a $956-\mathrm{km}^{2}$ basin. Land use in the study area is predominantly agricultural, comprising corn, soybeans [Glycine max (L.) Merr.], and alfalfa (Medicago sativa L.); $\mathrm{N}$ use in the watershed in 2003 was estimated to be $4666 \mathrm{Mg}$ (Fredrick et al., 2006) or about $51 \mathrm{~kg} \mathrm{ha}^{-1}$. Glacial till and Quaternary-age loess mantles the hills and forms terraces over sand and gravel deposits that make up the primary aquifer materials. Soils are fine-textured aeolian sand, silt, and loess. Precipitation and irrigation from ground-water withdrawals supply crop water needs. Ground-water discharge supports baseflow during the late growing season and winter; this discharge occurs where stream channels intersect the sand and gravel aquifer in the eastern part of the watershed where this study was conducted. The riverbed consists of sand and gravel, with a vertical hydraulic conductivity estimated at $7.5 \times 10^{-5} \mathrm{~m} \mathrm{~s}^{-1}$ (Essaid et al., 2008). The channel is about 20 to $30 \mathrm{~m}$ wide and has a surfacewater gradient of 0.001 . Within the 136-m-long study reach, during 2004 there was a large corn field on the left bank and riparian forest, pasture, and corn and soybean fields on the right bank. 


\section{Leary Weber Ditch, Indiana}

Leary Weber Ditch, a 7.2-km² watershed in central Indiana, is dominated by corn and soybean row crops (87\%), and fertilizer use contributed $47 \mathrm{Mg}$ of N in 2004 (Baker et al., 2006) or about $75 \mathrm{~kg} \mathrm{ha}^{-1}$. Rainfall supplies all crop water demand. The watershed is underlain by glacial till deposits, and soils are loams or silty loams. The till-derived soils have generally poor drainage, necessitating the use of tile drains and ditches; the flow in Leary Weber Ditch ceases when the tile drains stop flowing. The reach of Leary Weber Ditch chosen for this study is near the confluence with Sugar Creek, in an area of glacial outwash sand and gravel deposits with a riparian forest. The bed materials have vertical hydraulic conductivities estimated at $1.0 \times 10^{-4}$ to $7.9 \times 10^{-3} \mathrm{~m} \mathrm{~s}^{-1}$ (Essaid et al., 2008). The channel is about 3 to $4 \mathrm{~m}$ wide and has a surface-water gradient of 0.004 . Within the study reach, which is about $94 \mathrm{~m}$ long, there was riparian forest on the left bank and an overgrown pasture on the right bank.

\section{Morgan Creek, Maryland}

Morgan Creek drains a 31- $\mathrm{km}^{2}$ watershed in eastern Maryland, within the Chester River Basin. Crops including corn, soybeans, and small grains are planted in more than $75 \%$ of the basin, and $\mathrm{N}$ use in 2004 was estimated as $226 \mathrm{Mg}$ (Hancock and Brayton, 2006) or about $97 \mathrm{~kg} \mathrm{ha}^{-1}$. Rainfall supplies nearly all crop water demands. Soils are mainly well- to moderately well drained fine silt loams with some clay. The watershed is underlain by quartz sands and gravels (Owens and Denny, 1979; Owens and Minard, 1979). Ground-water flow in the surficial aquifer is generally from topographic highs toward discharge areas in or along Morgan Creek. Within the study reach, the entire floodplain consists of a 1- to 2-m thick layer of heavy silt and clay, having a vertical hydraulic conductivity estimated as $1 \times 10^{-10} \mathrm{~m} \mathrm{~s}^{-1}$, which is a typical value for these materials (Freeze and Cherry, 1979). This impervious clay layer prevents direct movement of ground water through the streambed; however, ground water discharges from seepage zones at the lateral margins of the floodplain and then flows across the floodplain in small channels and as diffuse sheet flow to the creek. The creek channel is about $4 \mathrm{~m}$ wide and has a surface-water gradient of 0.001 . In 2004, riparian forest on both sides of the 600-m-long study reach was bounded by pasture on the right side and a soybean field on the left.

\section{Methods}

Water samples were collected from the streambeds at depths ranging from 0.3 to $3.3 \mathrm{~m}$ at three to five points across each stream in two to five transects along the stream using stainless steel drive points with 0.9-cm-long screens. At most sites, the drive points were hammered into the streambed. At the DR2 Drain site, the silt and clay in the bed materials made it difficult to reliably collect water samples. Consequently, at this site piezometers and drive points were installed with sand packs in hand-augured holes and sealed with bentonite clay, and only two transects of 30 drive points were installed approximately $65 \mathrm{~m}$ apart; still only 16 drive points reliably produced water. At the Merced River and Maple Creek sites, five transects with a least five sampling points per transect were installed at depths ranging from 0.3 to $3.3 \mathrm{~m}$. In the Merced River the transects were about $50 \mathrm{~m}$ apart, and in Maple Creek they varied from 28 to $39 \mathrm{~m}$ apart. At the Leary Weber Ditch site, five transects were installed at distances ranging from 17 to $34 \mathrm{~m}$ apart; because of the narrowness of the channel, however, only three or four points were installed in each transect. Also at this site, layers of silt limited the number of depths at which drive points could be placed. At the Morgan Creek site, three parallel transects of 2.5$\mathrm{cm}$-diameter polyvinyl chloride (PVC) piezometers having $15-\mathrm{cm}$ long screens were installed in hand-augured holes completed below the clay layer, which provided watertight seals around the PVC pipe. Additional 5-cm-diameter PVC piezometers were installed in hand-augured holes at depths up to $3 \mathrm{~m}$ at the toe of a slope on the edge of the clay layer where ground-water seeps were present; these piezometers were sealed with bentonite clay. The Morgan Creek transects were separated by about 47 and $140 \mathrm{~m}$. To estimate the contribution of the seeps to the $\mathrm{NO}_{3}{ }^{-}$load of Morgan Creek, two synoptic surveys of all seeps along the study reach were conducted.

At two primary transects in each study area, samples were collected on three or four occasions using a peristaltic pump. Collection dates were chosen to coincide with pre- and post-fertilizer application times, mid-growing season, and post-harvest periods. Measurement of temperature, $\mathrm{pH}$, specific conductance, alkalinity, and dissolved oxygen $\left(\mathrm{O}_{2}\right)$ were made in the field as the samples were being collected, and the samples were subsequently analyzed for major cations and anions, nutrients, dissolved gases $\left(\mathrm{N}_{2}, \mathrm{Ar}, \mathrm{CO}_{2}\right.$, and $\left.\mathrm{CH}_{4}\right)$, the nitrogen $\left(\delta^{15} \mathrm{~N}\right)$ and oxygen $\left(\delta^{18} \mathrm{O}\right)$ isotopes of $\mathrm{NO}_{3}^{-}$and $\mathrm{N}_{2}$, and dissolved organic carbon (DOC). Cations and silica were analyzed by inductively coupled plasma spectroscopy, anions by ion chromatography, nutrients by colorimetric methods, and DOC by persulfate oxidation and infrared spectrometry (Fishman and Friedman, 1989; Fishman, 1993; Wershaw et al., 1987). A smaller set of measurements was made at all transects and sampling points during one high-flow and one low-flow period; a portable manometer (Winter et al., 1988) was used to measure hydraulic heads relative to stream stage at the time samples were collected. Pressure transducers with built-in electronic data loggers were used to monitor water levels continuously in 5-cm-diameter PVC piezometers with 15-cm-long screens at up to eight locations at each study site. At one location, multi-parameter probes connected to a data logger were used to monitor temperature, $\mathrm{pH}$, and specific conductance in the stream and at $0.5 \mathrm{~m}$ and 1 to $3 \mathrm{~m}$ below the streambed.

Equilibrium values of dissolved $\mathrm{O}_{2}$ were estimated on the basis of Henry's Gas Law coefficient, the concentration of oxygen in the atmosphere, average annual temperature, and atmospheric pressure. Oxidation-reduction state (redox state) was assessed for each sample using an approach based on the presence or absence of various redox couples similar to the method outlined by Paschke et al. (2007) and McMahon and Chapelle (2008). Additional information on analytical methods is presented by Capel et al. (2008) and Green et al. (2008).

To assess potential ground-water contributions to the groundwater/surface-water interface, transects of nested piezometers were installed along probable ground-water flow paths, terminating near each streambed study site. Chemical analyses of samples 
from these wells served as the basic reference for determining ground-water inputs to the streambeds. At the Leary Weber Ditch, Indiana site, nests of piezometers were installed in the outwash sand and gravel in the banks along the creek, and one deep (7 $\mathrm{m})$ ground-water piezometer was installed midway through the riparian zone. Samples were collected from these piezometers at the same time as those from the streambed sites and were analyzed for the same suite of constituents described previously. Additional information on these ground-water transect installations is provided by Capel et al. (2008) and Green et al. (2008).

\section{Dissolved Gases and Denitrification Progress}

Dissolved $\mathrm{N}_{2}$ and Ar concentrations were used to estimate the quantities in water of dissolved gases originating from atmospheric and biological sources. Samples for analysis of dissolved $\mathrm{N}_{2}$ and Ar were collected in filled serum bottles and analyzed by gas chromatography after creation of low-pressure headspace in the laboratory (USGS, 2007). Results of the analyses were corrected for solubility in sample water at laboratory temperatures and have typical uncertainties of \pm 1 to $2 \%$.

Dissolved gases may originate from equilibrium exchange with the atmosphere at the water's surface, dissolution of entrapped air bubbles, and production by reactions such as denitrification. Typically, dissolved gases include some fraction from bubbles of air that become trapped under recharging water and entrained in the saturated zone. As long as the hydrostatic pressure remains greater than the total pressure of gases in solution, degassing is unlikely (Blicher-Mathiesen et al., 1998). Similarly, denitrification produces $\mathrm{N}_{2}$, which remains in solution in recharging ground water. Recent literature has used the terms "excess air" to refer to atmospheric gases originating from entrained bubbles and "excess $\mathrm{N}_{2}$ " to refer to $\mathrm{N}_{2}$ originating from denitrification.

Excess air and excess $\mathrm{N}_{2}$ concentrations in water samples were estimated using the concentrations of $\mathrm{N}_{2}$ and $\mathrm{Ar}$, their known solubility in water (Weiss, 1970), the atmospheric pressure, and the recharge temperature (Heaton and Vogel, 1981; Vogel et al., 1981; Böhlke and Denver, 1995; McMahon and Böhlke, 1996; Puckett et al., 2002; Böhlke et al., 2002). This calculation required several assumptions, including (i) the only source of Ar was the atmosphere, (ii) the only sources of $\mathrm{N}_{2}$ were the atmosphere and denitrification, and (iii) excess air was not fractionated. It was assumed that all samples at each study site were recharged at approximately the same temperature, but with varying amounts of excess air. The latter assumption is considered to be the largest source of uncertainty because of possible variations in recharge temperatures, but in the absence of other noble gas measurements, this procedure minimizes errors associated with minor air contamination or partial degassing during sampling (Böhlke et al., 2002). The excess air concentration in each sample was calculated with

$$
\left[\operatorname{air}_{\text {bub }}\right]=\frac{\left[\mathrm{Ar}_{\text {meas }}\right]-\left[\mathrm{Ar}_{\text {equil }}\right](T, \text { elev })}{0.417}
$$

where $\left[\mathrm{air}_{\mathrm{bub}}\right]$ is the concentration of excess air from entrained bubbles $\left(\mathrm{cm}^{3} \mathrm{~L}^{-1}\right)$; $\left[\mathrm{Ar}_{\text {meas }}\right]$ is the measured concentration of $\mathrm{Ar}$ in the sample $\left(\mu \mathrm{mol} \mathrm{L}{ }^{-1}\right) ;\left[\mathrm{Ar}_{\text {equil }}\right](T$, elev $)$ is the concentration of $\mathrm{Ar}$ in humid air saturated water $\left(\mu \mathrm{mol} \mathrm{L}{ }^{-1}\right)$ at the temperature, $T$, and elevation, elev, of the water table; and 0.417 is the conversion factor for the quantity of Ar per volume of air $\left(\mu \mathrm{mol} \mathrm{cm}{ }^{-1}\right)$ at standard temperature and pressure of $1 \mathrm{~atm}$ and $0^{\circ} \mathrm{C}$. The excess $\mathrm{N}_{2}$ derived from denitrification was then calculated using

$$
\left[\mathrm{N}_{2, \text { bub }}\right]=\left[\text { air }_{\text {bub }}\right] \cdot 34.8
$$

and

$$
\left[\mathrm{N}_{2, \text { denit }}\right]=\left[\mathrm{N}_{2, \text { meas }}\right]-\left[\mathrm{N}_{2, \text { equil }}\right](T, \text { elev })-\left[\mathrm{N}_{2, \text { bub }}\right]
$$

where $\left[\mathrm{N}_{2, \text { bub }}\right]$ is the $\mathrm{N}_{2}$ from entrained bubbles $\left(\mu \mathrm{mol} \mathrm{L}{ }^{-1}\right)$, 34.8 is the conversion factor for the quantity of $\mathrm{N}_{2}$ per volume of air $\left(\mu \mathrm{mol} \mathrm{cm}{ }^{-3}\right)$ at standard temperature and pressure, $\left[\mathrm{N}_{2 \text {,denit }}\right]$ is the $\mathrm{N}_{2}$ from denitrification $\left(\mu \mathrm{mol} \mathrm{L}{ }^{-1}\right),\left[\mathrm{N}_{2 \text {,meas }}\right]$ is the measured concentration of $\mathrm{N}_{2}$ in the sample $\left(\mu \mathrm{mol} \mathrm{L}^{-1}\right)$, and $\left[\mathrm{N}_{2 \text {,equil }}\right](T$, elev $)$ is the concentration of $\mathrm{N}_{2}$ in humid airsaturated water as a function of $T$ and elev.

The cumulative progress of denitrification that has occurred in a ground-water sample is given by the concentration of $\mathrm{N}_{2 \text {,denit }}$ and can also be expressed as the fraction of the original $\mathrm{NO}_{3}{ }^{-}$that has been denitrified $\left(\xi_{\text {denit }}\right)$ :

$$
\xi_{\text {denit }}=\frac{2 \cdot\left[\mathrm{N}_{2, \text { denit }}\right]}{\left[\mathrm{NO}_{3}^{-}\right]^{0}}
$$

where $\left[\mathrm{NO}_{3}^{-}\right]^{0}$ is the reconstructed (initial) concentration of $\mathrm{NO}_{3}{ }^{-}$before denitrification:

$$
\left[\mathrm{NO}_{3}^{-}\right]^{0}=\left[\mathrm{NO}_{3}^{-}\right]+\left(2 \cdot\left[\mathrm{N}_{2, \text { denit }}\right]\right)
$$

For example, a value of 0.5 for $\xi_{\text {denit }}$ indicates that half of the original $\mathrm{NO}_{3}{ }^{-}$had been denitrified. Uncertainties in the reaction progress estimate were caused mainly by uncertainties in the assumed recharge conditions (temperature and excess air) affecting the calculation of $\left[\mathrm{N}_{2, \text { denit }}\right]$.

\section{Mineralogy}

Organic carbon is typically the most common source of electrons in many redox processes, particularly denitrification. However, various minerals may also supply $\mathrm{Mn}^{2+}, \mathrm{Fe}^{2+}, \mathrm{S}^{2-}$, and other reduced mineral phases as electron donors for denitrification. The mineralogy of sediments in the ground-water/surfacewater interface can therefore provide important information as to the controls on redox processes occurring there. The mineralogy of sediment cores collected within the aquifers and streambeds at each site was analyzed by X-ray diffraction. Samples from the cores were also analyzed for ferrous and total available iron content by extraction with $0.5 \mathrm{MHCl}$ and $0.5 \mathrm{MHCl}$ plus hydroxylamine, respectively (Lovley and Phillips, 1987). Acidvolatile sulfides plus pyrite were determined using methods developed by Canfield et al. (1986), Tuttle et al. (1986), Allen et al. (1991; 1993), USEPA (1996), and Bowles et al. (2003). Sulfide phases extracted by this method include pyrite, elemental sulfur, and acid-volatile monosulfides. Organic carbon content was determined by mass spectrometry before and after exposure to acid fumes to remove inorganic carbon (Révész and Qi, 2006). 
Table 1. Specific conductance and median concentrations of selected constituents in ground water, the streambed, and in streams of the five study sites. Ground-water and streambed samples were collected during March-October 2004; stream samples were collected during October 2003-August 2005.

\begin{tabular}{|c|c|c|c|c|c|c|c|c|}
\hline Site & Specific conductance & $\mathrm{Cl}^{-}$ & $\mathrm{O}_{2}$ & $\mathrm{NO}_{3}^{-}$ & $\mathrm{N}_{2, \text { denit }} \neq$ & $\mathrm{NH}_{4}^{+}$ & $\mathrm{Fe}^{2+}$ & DOC§ \\
\hline & $\mathrm{dS} \mathrm{m}^{-1}$ & $\longrightarrow$ & +2 & +2 & $\mathrm{~mol} \mathrm{~L}^{-1}$ & 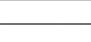 & 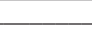 & - \\
\hline \multicolumn{9}{|l|}{ DR2 Drain, Washington } \\
\hline \multirow[t]{2}{*}{ Ground water } & $0.751(9)$ & $271(9)$ & $10(7)$ & $375(9)$ & $52(4)$ & $0(9)$ & $0(9)$ & $142(7)$ \\
\hline & $0.716-1.072$ & $104-335$ & $6-134$ & $29-487$ & $0-105$ & $0-7$ & $0-0$ & $117-475$ \\
\hline \multirow[t]{2}{*}{ Streambed } & $0.433(57)$ & $404(57)$ & $6(57)$ & $30(57)$ & $75(13)$ & $0(57)$ & $0(57)$ & $75(57)$ \\
\hline & $0.308-0.617$ & $167-483$ & $0-200$ & $0-337$ & $16-116$ & $0-8$ & $0-7$ & $33-242$ \\
\hline \multirow[t]{2}{*}{ Stream } & $0.458(33)$ & $348(34)$ & $253(33)$ & $243(33)$ & NAף & $2(33)$ & $1(34)$ & $308(33)$ \\
\hline & $0.340-0.711$ & 249-1412 & $144-330$ & $123-442$ & & $0-21$ & $0-4$ & $167-1742$ \\
\hline \multicolumn{9}{|l|}{ Merced River, California } \\
\hline \multirow[t]{2}{*}{ Ground water } & $0.458(14)$ & $446(14)$ & $6(14)$ & $160(14)$ & $282(5)$ & $0(14)$ & $0(14)$ & $75(14)$ \\
\hline & $0.282-0.573$ & $390-1526$ & $3-11$ & 0-1995 & $155-318$ & $0-16$ & $0-0$ & $42-133$ \\
\hline \multirow[t]{2}{*}{ Streambed } & $0.390(52)$ & $415(52)$ & $16(51)$ & $0(52)$ & $168(16)$ & $0(52)$ & $0(52)$ & $108(49)$ \\
\hline & $0.080-0.907$ & $48-1355$ & $0-181$ & $0-1501$ & $0-323$ & $0-74$ & $0-326$ & $50-508$ \\
\hline \multirow[t]{2}{*}{ Stream } & $0.136(15)$ & $214(12)$ & $288(15)$ & $106(14)$ & NA & $0(14)$ & NA & $250(9)$ \\
\hline & $0.056-0.243$ & $36-750$ & $219-419$ & $0-215$ & & $0-5$ & & $193-369$ \\
\hline \multicolumn{9}{|l|}{ Maple Creek, Nebraska } \\
\hline \multirow[t]{2}{*}{ Ground water } & $0.413(12)$ & $106(112)$ & $5(12)$ & $18(12)$ & $113(3)$ & $0(12)$ & $0(12)$ & $61(12)$ \\
\hline & $0.375-0.500$ & 89-129 & $0-25$ & $0-63$ & $23-161$ & $0-0$ & $0-6$ & $58-125$ \\
\hline \multirow[t]{2}{*}{ Streambed } & $0.444(149)$ & $111(53)$ & $71(153)$ & $61(54)$ & $120(7)$ & $0(54)$ & $0(53)$ & $92(47)$ \\
\hline & $0.193-0.660$ & 77-133 & $6-319$ & $0-429$ & $98-164$ & $0-375$ & $0-519$ & $58-1292$ \\
\hline \multirow[t]{2}{*}{ Stream } & $0.683(32)$ & $333(32)$ & $302(32)$ & $255(36)$ & NA & $0(36)$ & $0(31)$ & $388(26)$ \\
\hline & $0.233-0.910$ & $127-1645$ & $186-454$ & $0-425$ & & $0-87$ & $0-0$ & 154-1908 \\
\hline \multicolumn{9}{|l|}{ Leary Weber Ditch, Indiana } \\
\hline \multirow[t]{2}{*}{ Ground water } & $0.698(3)$ & $796(3)$ & $5(3)$ & $0(3)$ & $179(1)$ & $9(3)$ & $1(3)$ & $125(3)$ \\
\hline & $0.632-0.744$ & $454-1030$ & $3-5$ & $0-0$ & & $7-11$ & $1-4$ & $117-158$ \\
\hline \multirow[t]{2}{*}{ Streambed } & $0.631(167)$ & $759(48)$ & $22(125)$ & 0 (129) & $96(12)$ & $3(48)$ & $36(48)$ & $158(47)$ \\
\hline & $0.521-0.767$ & $516-1766$ & $0-228$ & $0-458$ & $80-179$ & $0-13$ & $1-74$ & $117-2083$ \\
\hline \multirow[t]{2}{*}{ Stream } & $0.513(42)$ & $706(33)$ & $278(33)$ & $490(48)$ & NA & $0(33)$ & $0(33)$ & $467(33)$ \\
\hline & $0.170-0.671$ & $136-870$ & $250-306$ & 7-904 & & $0-47$ & $0-1$ & $200-1200$ \\
\hline \multicolumn{9}{|l|}{ Morgan Creek, Maryland } \\
\hline \multirow[t]{2}{*}{ Ground water } & $0.154(29)$ & $354(31)$ & $248(26)$ & $727(31)$ & $0(8)$ & $0(31)$ & $0(31)$ & $42(30)$ \\
\hline & $0.092-0.224$ & $220-491$ & $0-344$ & $321-1206$ & $0-179$ & $0-0$ & $0-7$ & $33-108$ \\
\hline \multirow[t]{2}{*}{ Streambed/riparian zone } & $0.184(27)$ & $454(27)$ & $88(27)$ & $21(27)$ & $116(10)$ & $0(27)$ & $2(27)$ & $42(24)$ \\
\hline & $0.078-0.600$ & $70-2324$ & $0-356$ & $0-2568$ & $36-250$ & $0-7$ & $0-432$ & 25-92 \\
\hline \multirow[t]{2}{*}{ Stream } & $0.186(35)$ & 390 (29) & $206(26)$ & $195(42)$ & NA & $11(42)$ & $5(25)$ & $617(18)$ \\
\hline & $0.055-0.194$ & $175-570$ & $128-422$ & $43-345$ & & $0-57$ & $1-10$ & $233-833$ \\
\hline
\end{tabular}

† Values in parentheses are sample counts; data ranges are shown below the medians.

$\neq \mathrm{N}_{2, \text { denit }^{\prime}} \mathrm{N}_{2}$ from denitrification $\left(\mu \mathrm{mol} \mathrm{L}^{-1}\right)$.

$\S \mathrm{DOC}$, dissolved organic carbon.

ๆ NA, not available; gas samples were not collected in streams.

\section{Hydrology}

The movement of ground water within porous media, commonly referred to as the average linear velocity (Freeze and Cherry, 1979), is calculated from Darcy's law as:

$$
v=\frac{K\left(\frac{d h}{d l}\right)}{n}
$$

where $v$ is the average linear velocity (referred to as velocity for the remainder of the text) of the ground water, $K$ is the hydraulic conductivity, $n$ is the effective porosity, and $d h / d l$ is the hydraulic gradient (the change in head per unit of distance). The inverse of velocity provides a measure of water residence time. We used these relations along with head, hydraulic conductivity, and porosity to estimate velocities and residence times of water in the streambeds of our study sites. We believe that our study is the first to use an extensive analysis of velocity and residence times in the streambed, particularly at a variety of study sites across a range of hydrogeologic conditions.

\section{Results}

\section{DR2 Drain, Washington}

For each site, figures are provided with hydrologic and chemical results for the two primary transects that were sampled on approximately a quarterly basis and therefore have the largest set of physical and chemical measurements. These figures include two time periods to provide results for the post-fertilizer application period and post-growing season period. In addition to the presentation of the data in these figures, results for all transects and all time periods sampled are described in the remainder of this paper and are summarized in Table 1.

Head data provided evidence of large potentials for groundwater discharge to the streambed of the DR2 Drain during July and October 2004, respectively (Fig. 1 and 2); however, these large 
heads were probably due as much to the poorly permeable silt and clay layers in the bed as to upward ground-water flow potential. Flow directions based on analysis of equipotential lines also indicated the potential for discharge of deep ground water and shallow lateral flow but not for movement of surface water into the bed (Fig. 1 and 2). This last observation is also supported by results of temperature-flux-based modeling that indicated no surfacewater movement into the bed (Essaid et al., 2008).

Results of streamflow measurements at various places within the study reach to determine if certain stream segments were gaining or losing water (seepage runs), coupled with a $\mathrm{Br}^{-}$-tracer injection conducted during a companion study, indicated ground-water flux contributing about 4 to $10 \%$ and $6.8 \%$ of stream flow, respectively (Duff et al., 2006; 2008). Although the temperature-flux-based model indicated a smaller ground-water flux $(0.5-0.6 \%$ of stream flow), these results were based on long-term measurements, whereas the seepage runs and $\mathrm{Br}^{-}$injections were of limited durations. Temperatureflux-based modeling predicted ground-water velocities of 0.2 to $0.3 \mathrm{~m} \mathrm{~d}^{-1}$ and residence times of 3.4 to $5.6 \mathrm{~d} \mathrm{~m}^{-1}$ of streambed thickness (Essaid et al., 2008). Using the Darcy equation, heads measured at the time of sampling, and saturated vertical hydraulic conductivity and porosity values derived from the temperature-flux models, we estimated comparable velocities of 0.21 to $0.26 \mathrm{~m} \mathrm{~d}^{-1}$ and a median residence time of $4.4 \mathrm{~d} \mathrm{~m}^{-1}$ of streambed thickness.

Nitrate concentrations in the streambed in October were similar and in some cases identical to those in July (Fig. 1 and 2), and median $\mathrm{NO}_{3}{ }^{-}$concentrations $\left(39\right.$ and $43 \mu \mathrm{mol} \mathrm{L}^{-1}$ ) were virtually the same. Ammonium concentrations during both time periods were, with one exception, below the reporting limit. Nitrate concentrations at Transect 1 were lower just below the streambed than at greater depths. At Transect 2, $\mathrm{NO}_{3}{ }^{-}$concentrations in July and October generally were greater just below the streambed than at greater depths as a result of lateral inflow of $\mathrm{NO}_{3}{ }^{-}$-rich shallow ground water. This shallow ground water was also distinctly different in having $\mathrm{HCO}_{3}{ }^{-}$concentrations approximately twice those of other Transect 2 samples and was similar in magnitude to other ground water at the site.

A number of factors indicated that some denitrification had taken place in the streambed sediments. Overall, the median $\mathrm{NO}_{3}{ }^{-}$
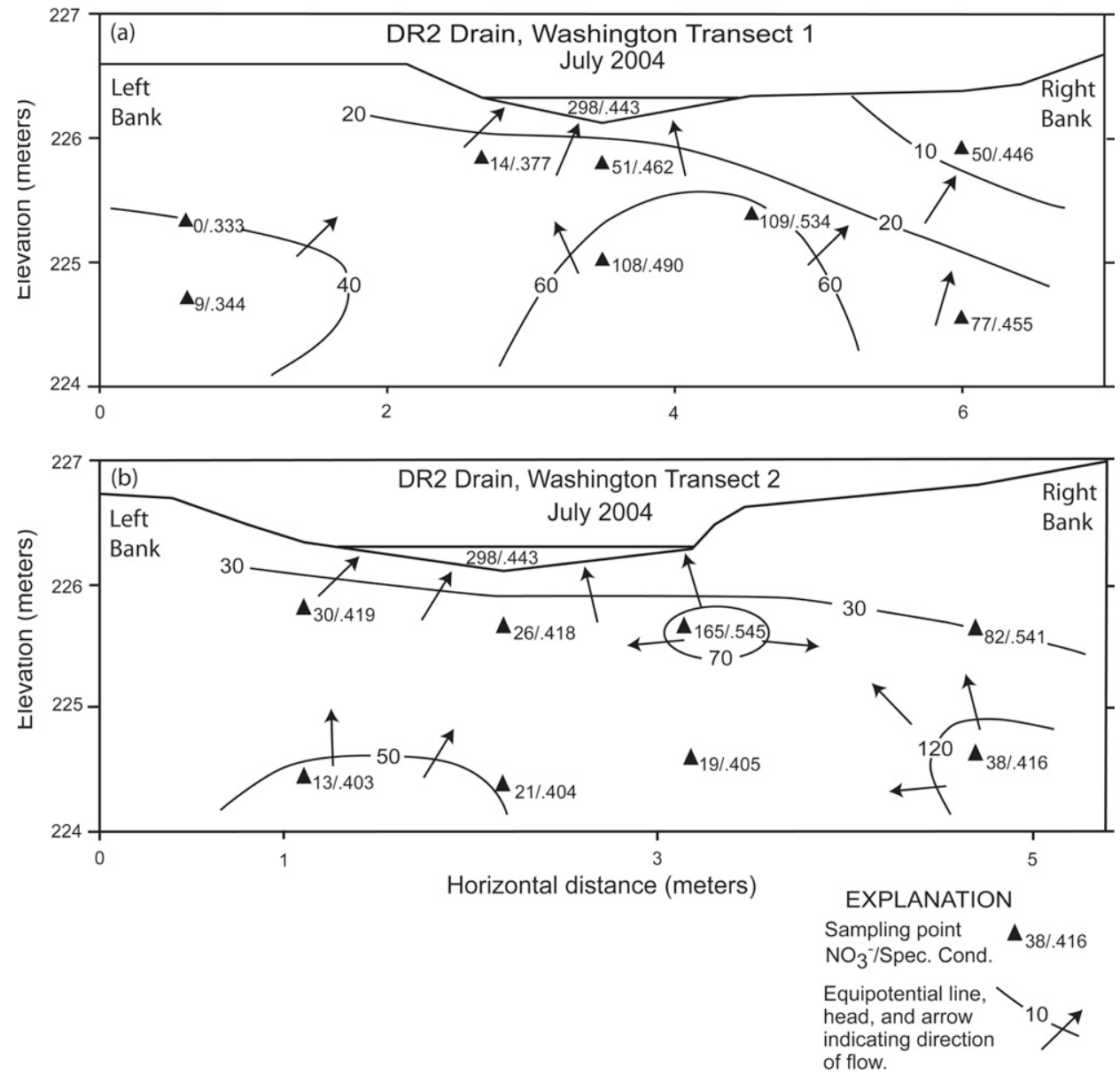

Fig. 1. Concentrations of $\mathrm{NO}_{3}{ }^{-}\left(\mu \mathrm{mol} \mathrm{L} \mathrm{L}^{-1}\right)$ and specific conductance $\left(\mathrm{dS} \mathrm{m}^{-1}\right)$ at the Washington study site in July 2004 at (a) Transect 1 and (b) Transect 2. Equipotential lines and flow directions are based on potentiometric heads $(\mathrm{cm})$ measured at the time of sampling.

concentration $\left(30 \mu \mathrm{mol} \mathrm{L}{ }^{-1}\right)$ in the streambed was much less than the median concentrations of ground water $\left(375 \mu \mathrm{mol} \mathrm{L}^{-1}\right)$ and surface water $\left(243 \mu \mathrm{mol} \mathrm{L}^{-1}\right)$ (Table 1$)$, indicating loss of $\mathrm{NO}_{3}^{-}$in the streambed. The median concentration of $\mathrm{O}_{2}$ in the streambed samples $\left(6 \mu \mathrm{mol} \mathrm{L}^{-1}\right)$ was much less than the equilibrium value $\left(312 \mu \mathrm{mol} \mathrm{L}^{-1}\right)$ and the redox state of streambed samples spanned the range of $\mathrm{O}_{2}, \mathrm{NO}_{3}^{-}, \mathrm{Mn}^{4+}$, and $\mathrm{Fe}^{3+}$ reduction. $\mathrm{Al}-$ though concentrations of organic carbon $\left(0.9 \mathrm{~g} \mathrm{~kg}^{-1}\right)$ and DOC ( $\left.75 \mu \mathrm{mol} \mathrm{L}{ }^{-1}\right)$ in bed sediment were low, other potential electron donors were present in the form of hornblende, extractable $\mathrm{Fe}^{2+}$ $\left(3600 \mathrm{mg} \mathrm{kg}^{-1}\right)$, and $\mathrm{S}^{-2}\left(220 \mathrm{mg} \mathrm{kg}^{-1}\right)$. The small concentrations of $\mathrm{Fe}^{2+}$ in solution and the presence of goethite in the sediments are consistent with oxidation and precipitation of reduced iron. Some $\delta^{15} \mathrm{~N}$ values $\left(8.52-12.18 \%\right.$ ) were enriched, $\mathrm{N}_{2 \text {,denit }}$ values ranged up to $116 \mu \mathrm{mol} \mathrm{L} \mathrm{L}^{-1}$, and denitrification reaction progress had a median value of 0.78 in the streambed samples compared with a value of 0 for ground-water samples. The net ground-water flux and persistence of $\mathrm{NO}_{3}^{-}$, however, resulted in a net increase of in-stream $\mathrm{NO}_{3}{ }^{-}$(Duff et al., 2006; 2008).

\section{Merced River, California}

Hydraulic heads in the Merced River were among the smallest measured at all five study sites (Fig. 3 and 4) with medians of 

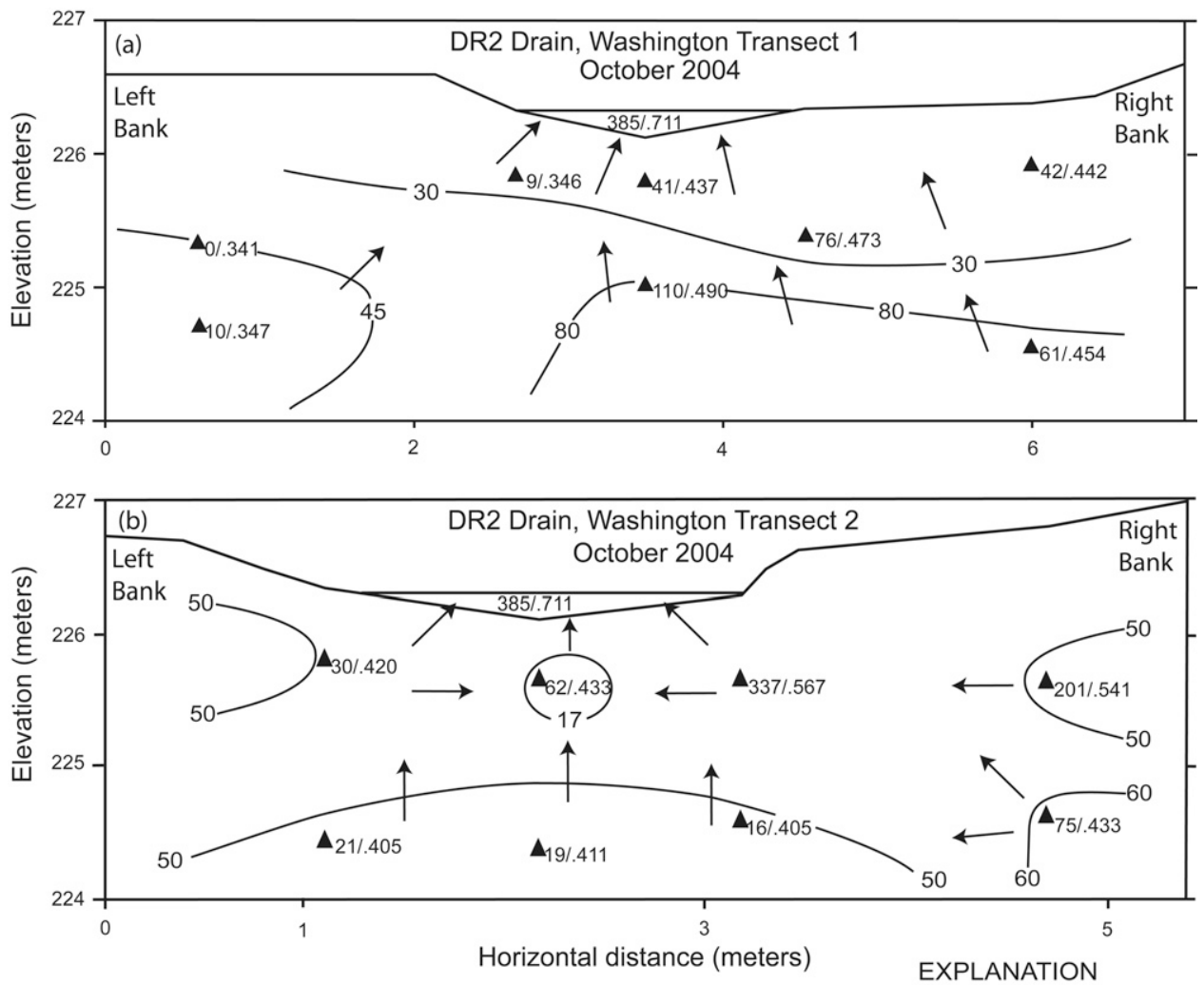

Fig. 2. Concentrations of $\mathrm{NO}_{3}^{-}\left(\mu \mathrm{mol} \mathrm{L}^{-1}\right)$ and specific conductance $\left(\mathrm{dS} \mathrm{m}^{-1}\right)$ at the Washington study site in October 2004 at (a) Transect 1 and (b) Transect 2. Equipotential lines and flow directions are based on potentiometric heads $(\mathrm{cm})$ measured at the time of sampling.

0 and $0.2 \mathrm{~cm}$ during March and October, respectively. During the March sampling, there was evidence of some surface-water movement into the streambed, particularly in the center of both primary transects (Fig. 3). The head data indicated much less surface-water movement into the bed during the October sample period (Fig. 4). Temperature-flux-based model results indicated a positive net flux during the March-December 2004 study period, with a velocity of $0.1 \mathrm{~m} \mathrm{~d}^{-1}$ and residence time of $24.4 \mathrm{~d} \mathrm{~m}^{-1}$ of bed thickness (Essaid et al., 2008). Our median calculated velocities based on all individual head measurements were 0 and $0.01 \mathrm{~m} \mathrm{~d}^{-1}$ for March and October, respectively, resulting in a median residence time of $34.7 \mathrm{~d} \mathrm{~m}^{-1}$ of bed thickness.

The continuously recorded head data in the study reach of the Merced River (Fig. 5a) revealed that during April-May and October-November 2004 there were head-gradient reversals accompanied by influxes of surface water into the streambed. These reversals were driven by large flows (Fig. 5b) and resulted in large depressions in specific conductance measured at 0.5 and $3 \mathrm{~m}$ below the streambed (Fig. $5 \mathrm{c}$ ). Because of the long residence times of water in the streambed, stream water that entered the bed remained there for long periods. The specific conductance at 0.5 and $3 \mathrm{~m}$ did not fully recover for almost $2 \mathrm{mo}$ after the head reversals that began in mid April (Fig. 5c). Also, the decrease in

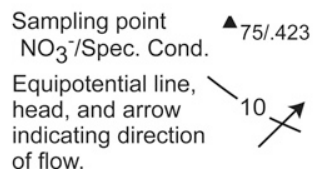

specific conductance at $3 \mathrm{~m}$ lagged behind the $0.5-\mathrm{m}$ depth by almost 2 mo (Fig. 5c).

During March, $\mathrm{NO}_{3}^{-}$concentrations at Transect 2 (Fig. 3a) were small, with a median of 21 $\mu \mathrm{mol} \mathrm{L}{ }^{-1} ; \mathrm{NO}_{3}^{-}$was not detected in most samples from the left and right banks, but concentrations of 347 to $404 \mu \mathrm{mol} \mathrm{L}^{-1}$ were measured in samples of deep ground water entering the center right section of the streambed. Nitrate concentrations at Transect 4 (Fig. $3 b$ ) were similar to those at Transect 2 , with a median of $29 \mu \mathrm{mol} \mathrm{L}^{-1}$, although concentrations on the right bank were larger than those on the left bank. These larger concentrations on the right bank at Transect 4 may be a consequence of the much narrower riparian strip present there than at Transect 2. By October, $\mathrm{NO}_{3}^{-}$concentrations had increased at Transects 2 and 4, with medians of 86 and $43 \mu \mathrm{mol} \mathrm{L}^{-1}$; distribution patterns remained similar to those in March.

On the basis of the specific conductance data and the flow directions inferred from head data, we believe that mixing of ground water with stream water having a $\mathrm{NO}_{3}{ }^{-}$concentration of 32 to $97 \mu \mathrm{mol} \mathrm{L}^{-1}$ can account for most of the observed variability in $\mathrm{NO}_{3}{ }^{-}$concentrations found in the upper $1 \mathrm{~m}$ of the streambed at the Merced River study site. Ammonium concentrations were negligible in most samples with a median below detection, except in isolated pockets where $\mathrm{DOC}$ concentrations were elevated above the median $\left(108 \mu \mathrm{mol} \mathrm{L}{ }^{-1}\right)$. Therefore, dissimilatory $\mathrm{NO}_{3}{ }^{-}$reduction (DNRA) to $\mathrm{NH}_{4}^{+}$cannot account for most of the decreased $\mathrm{NO}_{3}{ }^{-}$concentrations. There is evidence, however, that denitrification contributed to the low concentrations of $\mathrm{NO}_{3}{ }^{-}$in the streambed as well. For all sample sites and dates, the median $\mathrm{NO}_{3}{ }^{-}$ concentration in the streambed $\left(0 \mu \mathrm{mol} \mathrm{L}^{-1}\right)$ was much smaller than that for ground water $\left(160 \mu \mathrm{mol} \mathrm{L}^{-1}\right)$ and/or surface water $\left(106 \mu \mathrm{mol} \mathrm{L}^{-1}\right)$. Values of $\delta^{15} \mathrm{~N}(27.44-51.88 \%$ o) were the most enriched that were measured among all of the sites, $\mathrm{N}_{2, \text { denit }}$ values ranged up to $323 \mu \mathrm{mol} \mathrm{L} \mathrm{L}^{-1}$, and denitrification reaction progress had a value of 1.0 in the streambed samples compared with a median of 0.25 for ground-water samples.

The median concentration of $\mathrm{O}_{2}$ in the streambed samples $\left(16 \mu \mathrm{mol} \mathrm{L}^{-1}\right)$ was significantly less than the equilibrium value $\left(301 \mu \mathrm{mol} \mathrm{L}^{-1}\right)$, and the redox state of streambed samples spanned the range of $\mathrm{O}_{2}, \mathrm{NO}_{3}^{-}, \mathrm{Mn}^{4+}$, and $\mathrm{Fe}^{3+}$ reduction. Organic carbon levels in the bed sediment 
$\left(0.6 \mathrm{~g} \mathrm{~kg}^{-1}\right)$ and as DOC (108 $\mu \mathrm{mol} \mathrm{L}^{-1}$ ) were relatively low, as was $\mathrm{S}^{2-}\left(2 \mathrm{mg} \mathrm{kg}^{-1}\right)$, but other electron donors were present in the form of extractable $\mathrm{Fe}^{2+}$ (1200 $\mathrm{mg} \mathrm{kg}^{-1}$ ) and hornblende. Dissolved $\mathrm{Fe}^{2+}$ concentrations reached $326 \mu \mathrm{mol} \mathrm{L}^{-1}$ in reduced zones, and the presence of goethite was consistent with the oxidation of $\mathrm{Fe}^{2+}$ and subsequent precipitation of this mineral.

\section{Maple Creek, Nebraska}

Heads in the Maple Creek streambed (Fig. 6 and 7) were generally positive throughout the year, although there were reversals in head during some large storm flows. Unlike in the Merced River, we saw no widespread evidence of surface water remaining in the bed beyond the flood events. One exception was at Transect 2 in October (Fig. 7) when the heads measured in the streambed on the center left side of the stream were negative, and specific conductance measurements indicated that stream water had entered the bed. Flow directions based on equipotential lines and heads indicated that the streambed was dominated by deep ground-water influxes in the stream center and some shallow lateral flow, particularly from the left bank at Transect 4 . Results of $\mathrm{Br}^{-}$ injection conducted during a companion study (Duff et al., 2006; 2008 ) indicated a ground-water influx equal to $12 \%$ of stream flow through the study reach. Temperature-flux-based modeling predicted an average ground-water velocity of $1.48 \mathrm{~m} \mathrm{~d}^{-1}$, resulting in a residence time of $0.7 \mathrm{~d} \mathrm{~m}^{-1}$ of streambed thickness (Essaid et al., 2008). Using heads measured at the time of sampling at all sites, we calculated median velocities of 0.17 to $0.44 \mathrm{~m} \mathrm{~d}^{-1}$ and a median residence time of $1.76 \mathrm{~d} \mathrm{~m}^{-1}$ of bed thickness.

Like the Merced River site, $\mathrm{NH}_{4}^{+}$concentrations were below the reporting limit in all samples except those having DOC concentrations greater than the median value $\left(92 \mu \mathrm{mol} \mathrm{L}^{-1}\right)$, indicating that DNRA was not a major factor in controlling the fate of $\mathrm{NO}_{3}{ }^{-}$. Concentrations of $\mathrm{NO}_{3}{ }^{-}$at the two primary transects (Transects 2 and 4) were similar for the two sampling periods; however, concentrations at Transect 4 were about double those at Transect 2 (Fig. 6 and 7). One reason for the higher $\mathrm{NO}_{3}{ }^{-}$concentrations at Transect 4 was the influx of shallow ground water from the left bank where a large corn field was located. In general, $\mathrm{NO}_{3}{ }^{-}$concentrations showed no consistent increasing or decreasing trends through the streambed. In a few locations, however, $\mathrm{NO}_{3}{ }^{-}$decreased markedly, and there was a decrease in October at Transect 2 where surface water infiltrated the streambed (Fig. 7a). Median $\mathrm{NO}_{3}{ }^{-}$concentrations in upland ground water were lower $\left(18 \mu \mathrm{mol} \mathrm{L}^{-1}\right)$ than that in the streambed $\left(61 \mu \mathrm{mol} \mathrm{L}{ }^{-1}\right)$ and larger in the stream itself $\left(255 \mu \mathrm{mol} \mathrm{L}^{-1}\right)$. This pattern of increasing concentration of $\mathrm{NO}_{3}{ }^{-}$resulted from the fact that the ground-water sampling network did not include the left bank corn field, and therefore $\mathrm{NO}_{3}{ }^{-}$concentrations were biased low. A companion study using a $\mathrm{Br}^{-}$tracer concluded that ground-water discharge contributed substantially to the surfacewater $\mathrm{NO}_{3}{ }^{-}$load in the study reach (Duff et al., 2006; 2008).

The data for Maple Creek also indicated that redox conditions were conducive for denitrification in the streambed. Median $\mathrm{O}_{2}$ in the streambed samples $\left(71 \mu \mathrm{mol} \mathrm{L}^{-1}\right)$ was substantially less than the equilibrium value $\left(330 \mu \mathrm{mol} \mathrm{L}^{-1}\right)$, and the redox state of streambed samples spanned the range of $\mathrm{O}_{2}, \mathrm{NO}_{3}{ }^{-}$, and $\mathrm{Fe}^{3+}$ reduction. Organic carbon in the bed sediment $\left(0.2 \mathrm{~g} \mathrm{~kg}^{-1}\right)$ was relatively low, as were levels of $\mathrm{S}^{2-}\left(0.5 \mathrm{mg} \mathrm{kg}^{-1}\right)$ and $\mathrm{Fe}^{2+}$ $\left(400 \mathrm{mg} \mathrm{kg}^{-1}\right.$ ). Although the median DOC was only $92 \mu \mathrm{mol} \mathrm{L}^{-1}$ in the streambed samples, concentrations ranged as high as $1292 \mu \mathrm{mol} \mathrm{L}^{-1}$. Values of $\delta^{15} \mathrm{~N}(7.33-13 \%$ o) were only slightly enriched, $\mathrm{N}_{2, \text { denit }}$ values ranged up to $164 \mu \mathrm{mol} \mathrm{L} \mathrm{L}^{-1}$, and denitrification reaction progress had a median value of 0.64 in the stream- 

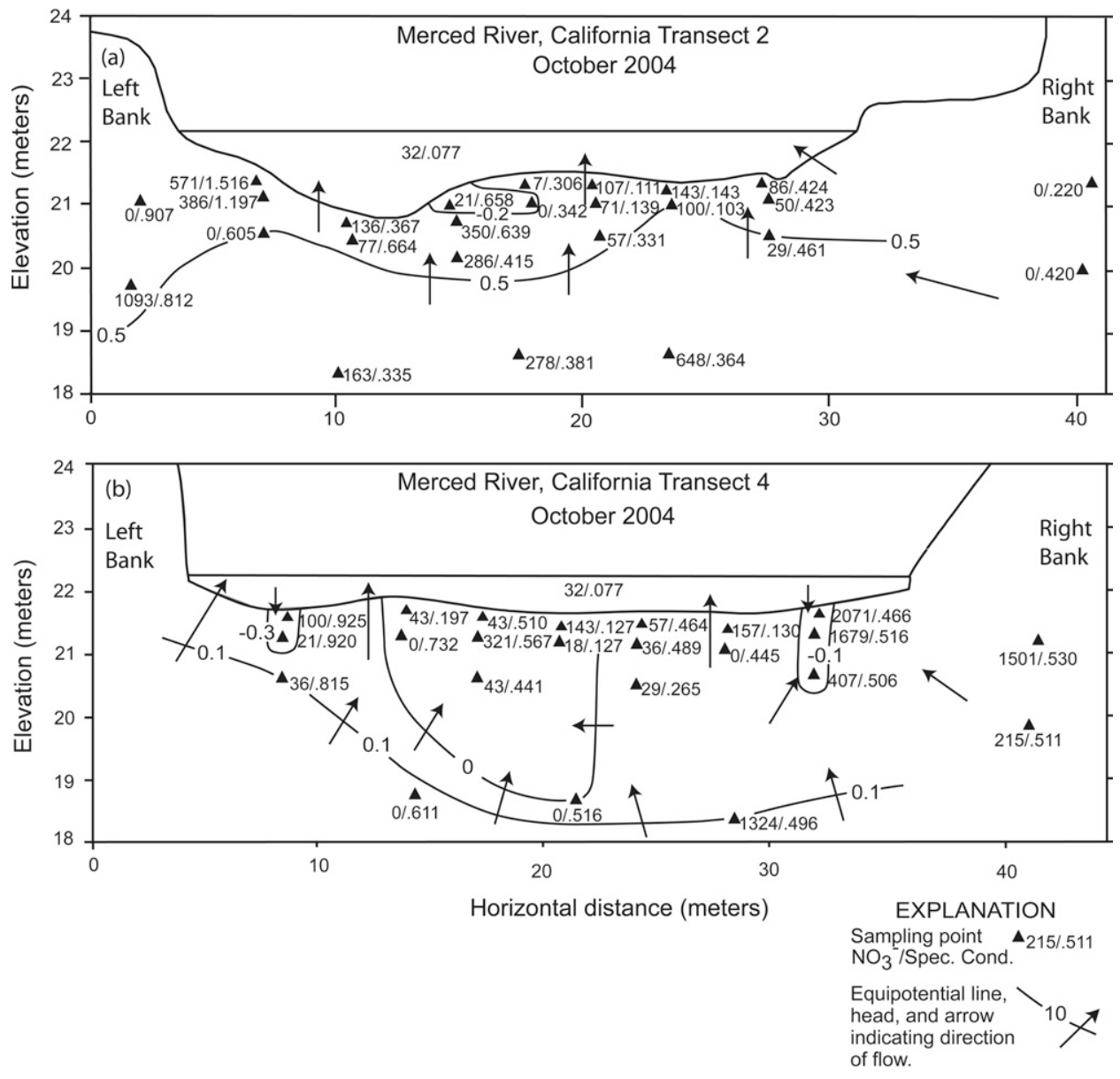

Fig. 4. Concentrations of $\mathrm{NO}_{3}{ }^{-}\left(\mu \mathrm{mol} \mathrm{L} \mathrm{L}^{-1}\right)$ and specific conductance $\left(\mathrm{dS} \mathrm{m}^{-1}\right)$ at the California study site in October 2004 at (a) Transect 2 and (b) Transect 4. Equipotential lines and flow directions are based on potentiometric heads $(\mathrm{cm})$ measured at the time of sampling.

bed samples.

\section{Leary Weber Ditch, Indiana}

Hydraulic heads in the streambed at Leary Weber Ditch (Fig. 8 and 9) were comparable to those in Maple Creek; the streambed materials at these sites are similar-coarse grained sediments containing layers of silt that act as confining layers. At Transect 1 , a silt layer was present on the left side of the stream at a depth of about 0.12 to $0.15 \mathrm{~m}$ with an average thickness of $0.24 \mathrm{~m}$. At Transect 3 , a silt layer ranging from 0.3 to $0.45 \mathrm{~m}$ thick extended across the entire streambed at a depth of $0.5 \mathrm{~m}$ at the left bank, $0.06 \mathrm{~m}$ in the middle, and at the streambed surface on the right bank. Although the hydraulic conductivity of the silt was low relative to that of the coarse-grained outwash sands and gravels, there was some flow through the silt layers (Essaid et al., 2008). The net effect of the layer at Transect 1 was that water moved preferentially through the streambed on the right side (Fig. 8a and 9a).

Another important factor at this site was the cessation of stream flow after the tile drains and ditches ceased flowing in late summer. As ground-water levels decreased, this led to head reversals in the streambed and the influx of surface water into the bed (Fig. 9). We also noted downward heads at Transect 4 (Fig. 10) throughout the study period. The piezometers at
Transect 4 were installed in a gravel bar at the downgradient end of a pool, which resulted in movement of surface water into the streambed to a depth of about 0.5 to $1 \mathrm{~m}$. Temperatureflux-based modeling predicted an average ground-water velocity of 0.12 to $0.85 \mathrm{~m} \mathrm{~d}^{-1}$, resulting in residence times of 1.2 to $8.5 \mathrm{~d} \mathrm{~m}^{-1}$ of streambed thickness (Essaid et al., 2008). Calculations based on heads measured at the time of sampling indicated comparable median velocities of 0.15 to $2.22 \mathrm{~m} \mathrm{~d}^{-1}$ and a median residence time of $2.2 \mathrm{~d} \mathrm{~m}^{-1}$ of bed thickness.

We detected $\mathrm{Fe}^{2+}$ in concentrations up to $74 \mu \mathrm{mol} \mathrm{L}^{-1}$ (Fig. 8 and 9), with the exception of Transect 4, where we noted head reversals and surface-water infiltration (Fig. 10). This influx of surface water at Transect 4 resulted in the only detections of $\mathrm{NO}_{3}{ }^{-}$found in the streambed at Leary Weber Ditch during the study. Overall, $\mathrm{O}_{2}$ in the streambed samples $\left(22 \mu \mathrm{mol} \mathrm{L}^{-1}\right)$ was less than the equilibrium value $\left(326 \mu \mathrm{mol} \mathrm{L}^{-1}\right)$, and redox state was dominated by $\mathrm{Fe}^{3+}$-reducing conditions, resulting in rapid loss of $\mathrm{NO}_{3}{ }^{-}$once surface water moved into the streambed. Ammonium concentrations in Leary Weber Ditch (Table 1) had the largest median value $\left(3 \mu \mathrm{mol} \mathrm{L} \mathrm{L}^{-1}\right)$ among the study sites. This large median concentration of $\mathrm{NH}_{4}^{+}$was partly due to the equally large median values in ground water $\left(9 \mu \mathrm{mol} \mathrm{L}^{-1}\right)$ and to the large values of DOC, indicating a potential for $\mathrm{NO}_{3}{ }^{-}$reduction. There were ample electron donors available in the bed sediment, including organic carbon $\left(17 \mathrm{~g} \mathrm{~kg}^{-1}\right)$, DOC $\left(158 \mu \mathrm{mol} \mathrm{L}^{-1}\right), \mathrm{Fe}^{2+}\left(2200 \mathrm{mg} \mathrm{kg}^{-1}\right)$, and $\mathrm{S}^{2-}$ $\left(420 \mathrm{mg} \mathrm{kg}^{-1}\right)$. Values of $\mathrm{N}_{2, \text { denit }}$ ranged up to $179 \mu \mathrm{mol} \mathrm{L}^{-1}$, and denitrification reaction progress (1.0) was complete.

\section{Morgan Creek, Maryland}

As a result of the thick confining layer of silt and clay in the floodplain of Morgan Creek (Fig. 11), heads as great as $0.48 \mathrm{~m}$ were measured over a streambed thickness of $1.1 \mathrm{~m}$. Assuming typical values for saturated vertical hydraulic conductivity $(1 \times$ $10^{-10} \mathrm{~m} \mathrm{~s}^{-1}$ ) and porosity (0.5) for these materials (Freeze and Cherry, 1979), the velocity through the streambed was estimated to be $7.5 \times 10^{-6} \mathrm{~m} \mathrm{~d}^{-1}$, which would effectively eliminate the possibility of any direct ground-water/surface-water interaction. However, where ground water discharged through the sand aquifer 
along the margins of the floodplain, we estimated, on the basis of typical literature values (Freeze and Cherry, 1979) for saturated vertical hydraulic conductivity $\left(1 \times 10^{-4} \mathrm{~m} \mathrm{~s}^{-1}\right)$ and porosity ( 0.3$)$, a velocity of 4.32 to $6.6 \mathrm{~m} \mathrm{~d}^{-1}$ and a mean residence time of $0.28 \mathrm{~d} \mathrm{~m}^{-1}$. The seeps created by this ground-water discharge resulted in a small net increase in $\mathrm{NO}_{3}^{-}$concentrations and a $9.2 \%$ increase in stream flow (Duff et al., 2006; 2008).

Maximum concentrations of $\mathrm{NO}_{3}{ }^{-}\left(2568 \mu \mathrm{mol} \mathrm{L}^{-1}\right)$ below the clay confining layer at Morgan Creek were the largest measured among all five study sites; however, median $\mathrm{NO}_{3}{ }^{-}$ concentrations there $\left(21 \mu \mathrm{mol} \mathrm{L}{ }^{-1}\right)$ were substantially less than in upgradient ground water $\left(727 \mu \mathrm{mol} \mathrm{L}^{-1}\right)$, reflecting more reduced conditions, longer flowpaths, and longer residence times. Median $\mathrm{NO}_{3}{ }^{-}$concentrations in the seep channels $\left(488 \mu \mathrm{mol} \mathrm{L}^{-1}\right)$ were also much lower than those in ground water, indicating substantial loss of $\mathrm{NO}_{3}{ }^{-}$in the organic-rich sediments in the seep discharge zones or in the seep channels. Dissolved organic carbon $\left(42 \mu \mathrm{mol} \mathrm{L}^{-1}\right)$ in ground water at Morgan Creek was the smallest median value among the five sites, and although concentrations of organic carbon in the ground-water system sediments ranged from 0.2 to $9 \mathrm{~g} \mathrm{~kg}^{-1}$, a concentration of $76 \mathrm{~g} \mathrm{~kg}^{-1}$ in one seep zone was the largest measured in surface sediments during the study. Concentrations of extractable $\mathrm{Fe}^{2+}$ $\left(370 \mathrm{mg} \mathrm{kg}^{-1}\right)$ and $\mathrm{S}^{2-}\left(23 \mathrm{mg} \mathrm{kg}^{-1}\right)$ were relatively low; however, there were pockets of the ground-water system that contained up to $13,000 \mathrm{mg} \mathrm{kg}^{-1}$ $\mathrm{Fe}^{2+}$, which is probably associated with the glauconitic sands found in the aquifer. Consequently, although the ground water and confined sediments were generally oxic (Table 1), redox conditions spanned the range of $\mathrm{O}_{2}$, $\mathrm{NO}_{3}{ }^{-}, \mathrm{Mn}^{4+}$, and $\mathrm{Fe}^{3+}$ reduction. Most $\delta^{15} \mathrm{~N}$ values (3.07-5.98\%) did not differ greatly from the original sources (3.75-3.85\%o) estimated from mass balance and soil measurements and in two cases (19.75-20.48\%o) seem to have been the result of an animal-
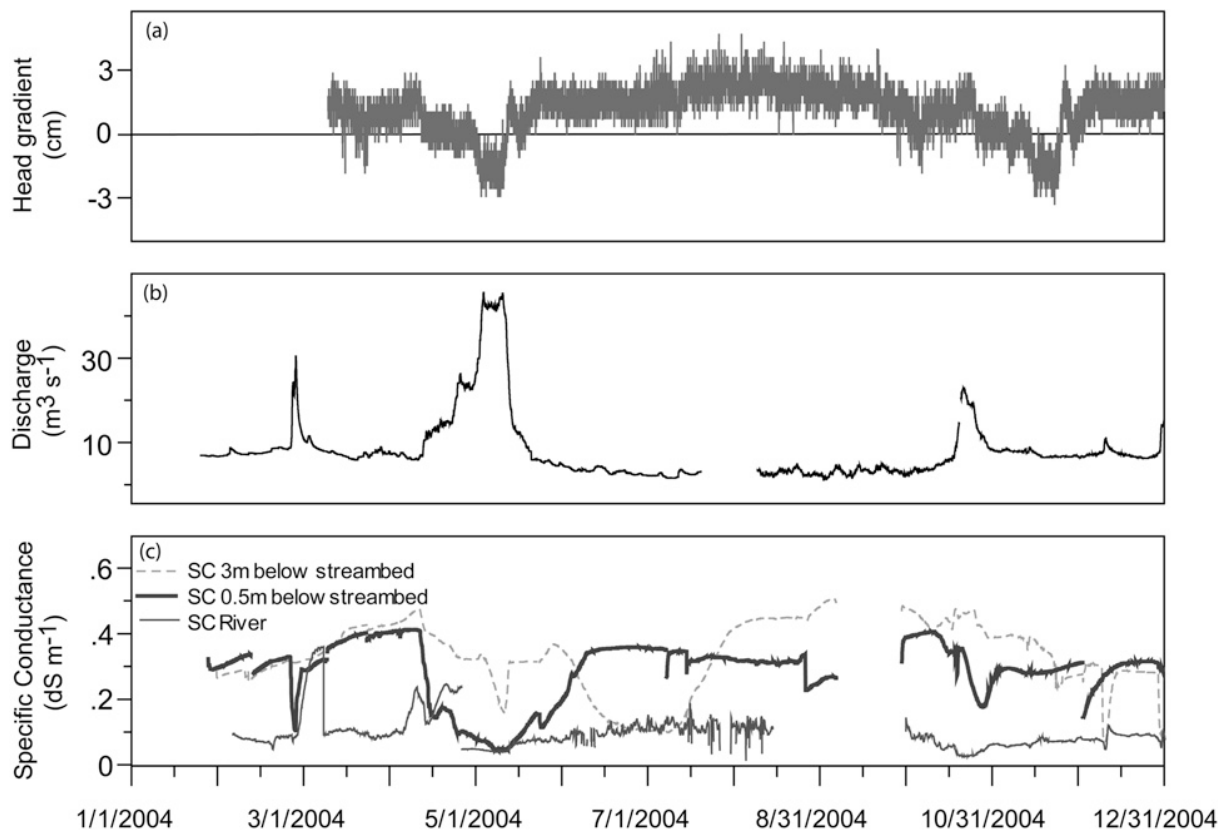

Fig. 5. Plots of (a) head gradient, (b) stream discharge, and (c) specific conductance for the Merced River, California, at the midpoint of Transect 2 at 0.5 and $3 \mathrm{~m}$ below the streambed during the 2004 study period.
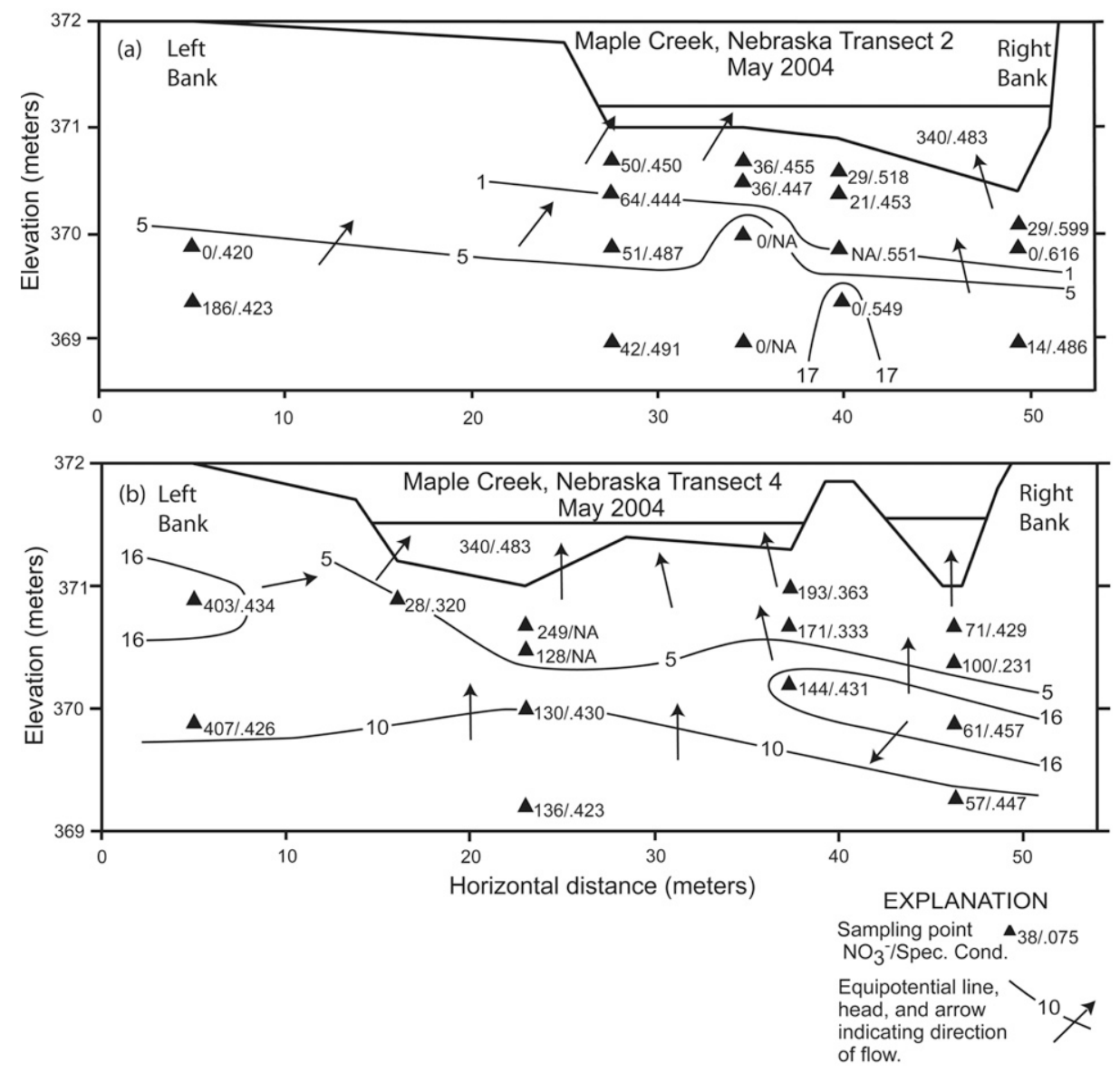

Fig. 6. Concentrations of $\mathrm{NO}_{3}^{-}\left(\mu \mathrm{mol} \mathrm{L}^{-1}\right)$ and specific conductance $\left(\mathrm{dS} \mathrm{m}^{-1}\right)$ at the Nebraska study site in May 2004 at (a) Transect 2 and (b) Transect 4. Equipotential lines and flow directions are based on potentiometric heads $(\mathrm{cm})$ measured at the time of sampling. NA, data not available. 

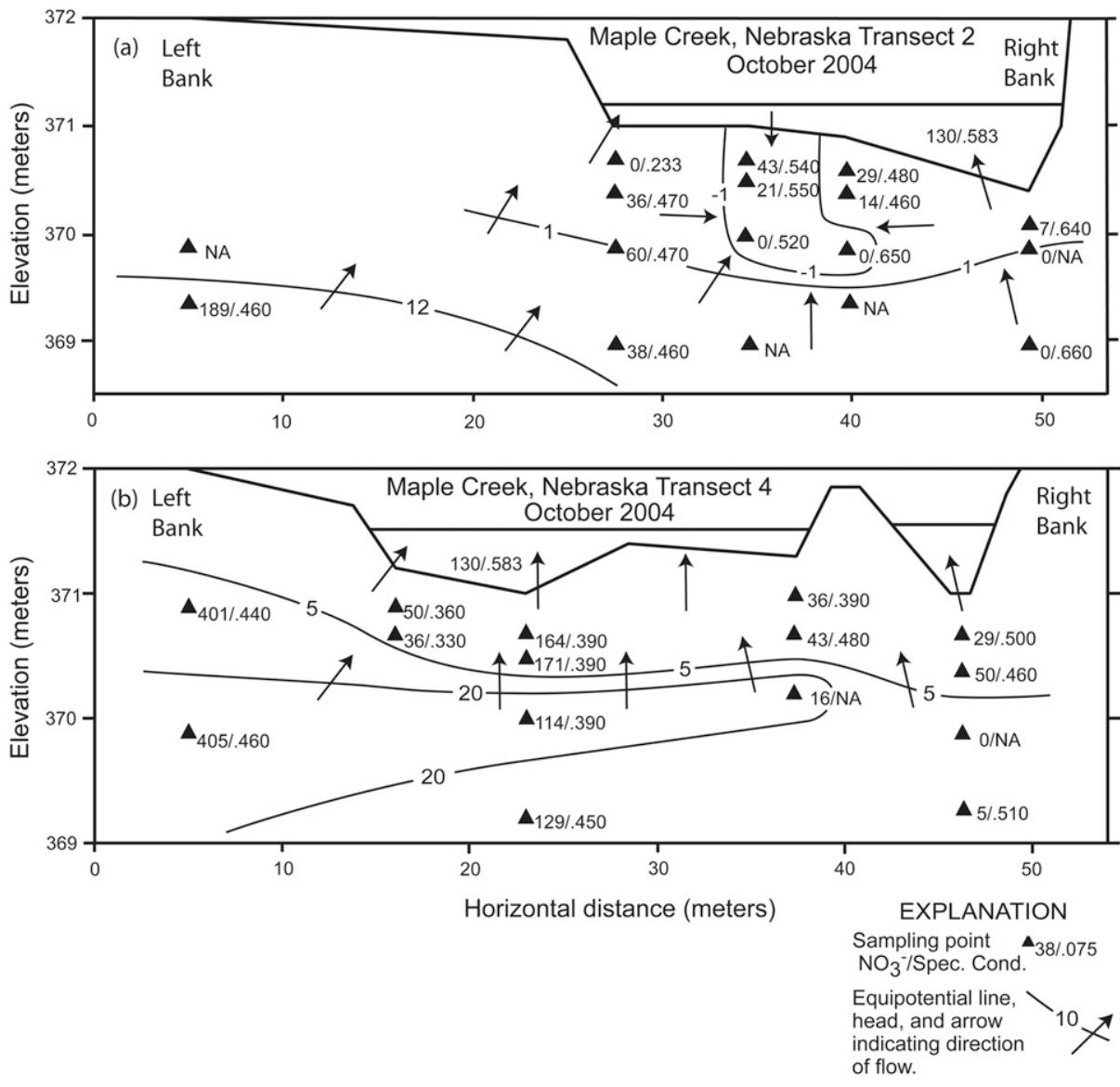

Fig. 7. Concentrations of $\mathrm{NO}_{3}^{-}(\mu \mathrm{mol} \mathrm{L}-1)$ and specific conductance $\left(\mathrm{dS} \mathrm{m}^{-1}\right)$ at the Nebraska study site in October 2004 at (a) Transect 2 and (b) Transect 4. Equipotential lines and flow directions are based on potentiometric heads $(\mathrm{cm})$ measured at the time of sampling. NA, data not available.

inputs, ground-water discharge in these more arid Pacific Coast watersheds was estimated to be 5 to 40 times less than in the Maple Creek and Leary Weber Ditch sites (Essaid et al., 2008).

The moderate ground-water heads beneath Maple Creek in combination with the coarse-grained bed sediments and small surface-water gradient $(0.1 \%)$ created conditions that resulted in the largest ground-water discharge measured during the study (Essaid et al., 2008). Surface-water infiltration into the bed was mainly limited to stormflow-driven events of short duration, with the relatively short residence times indicating that ground water rapidly displaced surface water in the bed sediments. Because the Leary Weber Ditch study reach is in a relatively isolated glacial-outwash sand and gravel deposit surrounded by glacial till, the groundwater system that affects flow in the ditch is small and local, and stream flow is largely dependent on tile-drain flows. During the winter and spring, groundwater levels at Leary Weber Ditch are high enough to produce moderate heads and discharge rates comparable to those in Maple Creek, and residence times bracket those of Maple Creek. However, because the surface area of

manure source. Although ground water and confined sediments contained $\mathrm{N}_{2 \text {,denit }}$ ranging from 0 to $250 \mu \mathrm{mol} \mathrm{L}^{-1}$, denitrification reaction progress was negligible.

\section{Discussion}

\section{Hydrogeologic Controls}

The physical properties of the bed sediments exerted a strong control on ground-water/surface-water interactions at all five sites. At the Merced River site, the study reach is directly down stream from the transition from a losing to a gaining reach and has negligible surface-water slope, and the ground-water flow system discharges across a wide $(\sim 30 \mathrm{~m})$ stream channel. This combination of factors results in small ground-water/surface-water gradients, small ground-water flux rates, and much longer water residence times than at any of the other study sites. The DR2 Drain watershed had a water-table slope similar to that at the Merced River watershed, with a discharge zone in the lower part of the basin, which resulted in perennial stream flow and groundwater flux rates about an order of magnitude greater than in the Merced River (Essaid et al., 2008). Because the flux rates are expressed on a unit area basis and because the Merced River has a much greater width and therefore greater surface area, groundwater contributions were about the same. Even with the irrigation
Leary Weber Ditch is about an order of magnitude smaller, total discharge is as well. Surface-water infiltration into the bed of Leary Weber Ditch during the winter and spring months is limited mainly to coarse-grained gravel deposits at the foot of pools and during stormflows. As surface flow ceases and ground-water levels decrease during the summer months, head potentials reverse, and surface water in the isolated pools infiltrates the streambed.

Morgan Creek is unique among the study sites in having a streambed that acts as a ground-water confining unit. Consequently, all ground-water/surface-water interactions in the study reach are the result of ground-water discharge along the margins of the floodplain and unidirectional flow across the floodplain to the stream. Although this ground-water discharge accounted for only a small gain in flow through the study reach $(\sim 9.2 \%)$, it has been estimated that slightly more than half (59\%) of the streamflow in the watershed as a whole originates as ground-water discharge (Hancock and Brayton, 2006).

At sites where streambed materials consist of fine-grained sediments with correspondingly small vertical hydraulic conductivities (DR2 Drain and Morgan Creek), there was little or no ground-water discharge through the streambed and no detectable hyporheic zone. Conversely, at the three sites composed of coarsegrained sediments (Merced River, Maple Creek, and Leary Weber Ditch), surface water reached depths up to $3 \mathrm{~m}$, and the infiltra- 
tion of surface water into the coarse-grained beds was offset by ground-water discharge. This relation between sediment properties, including hydraulic conductivity, and ground-water/surface-water interactions agrees with results described by Valett et al. (1996) for three high-gradient streams with gradients up to $11 \%$. It also supports the contention of Valett et al. (1996) that lentic bed interactions are dominated by diffusion, whereas lotic streambed interactions are dominated by advection. Hill and Lymburner (1998) found that the size of the interaction zone as well as water exchange across the ground-water/surface-water interface increased with alluvial hydraulic conductivity.

The inverse relation between ground-water heads and surfacewater infiltration in the Merced River, Maple Creek, and Leary Weber Ditch resulted in penetration of surface water deep into the streambed, but only during high flows when surface-water heads increased. One exception to this was in Leary Weber Ditch in a gravel bar at the end of a pool where surface water penetrated to a depth of about $1 \mathrm{~m}$. Streambed topography such as that in pool and riffle sequences has been shown in the past to exert strong controls on hyporheic exchanges, which are driven by the creation of strong surface-water heads in these locations (Harvey and Bencala, 1993; Valett et al., 1996; Hill et al., 1998; Opdyke et al., 2006). However, Hill and Lymburner (1998) reported that strong ground-water heads restricted surfacewater movement into the streambed. In low-gradient streams, such as those we studied (gradients $\cong 0-0.4 \%$ ), storm events may therefore play an important role as forcing functions that can overcome ground-water heads and move large amounts of surface water into the streambed.

\section{Biogeochemical Processes}

Denitrification is the most commonly studied process related to $\mathrm{NO}_{3}{ }^{-}$retention in hyporheic zones, and organic carbon, either dissolved or particulate, is the most commonly studied electron donor controlling denitrification (Triska et al., 1989; Vervier et al., 1992; Triska et al., 1993; Findlay and Sobczak, 1996; Jones and Holmes, 1996; Sobczak and Findlay, 2002; Storey et al., 2004). In an extensive review of denitrification processes, Korom (1992) discussed autotrophic processes that can use $\mathrm{Mn}^{2+}, \mathrm{Fe}^{2+}$, $\mathrm{S}^{2-}$, and reduced mineral phases as electron donors for denitrifi-
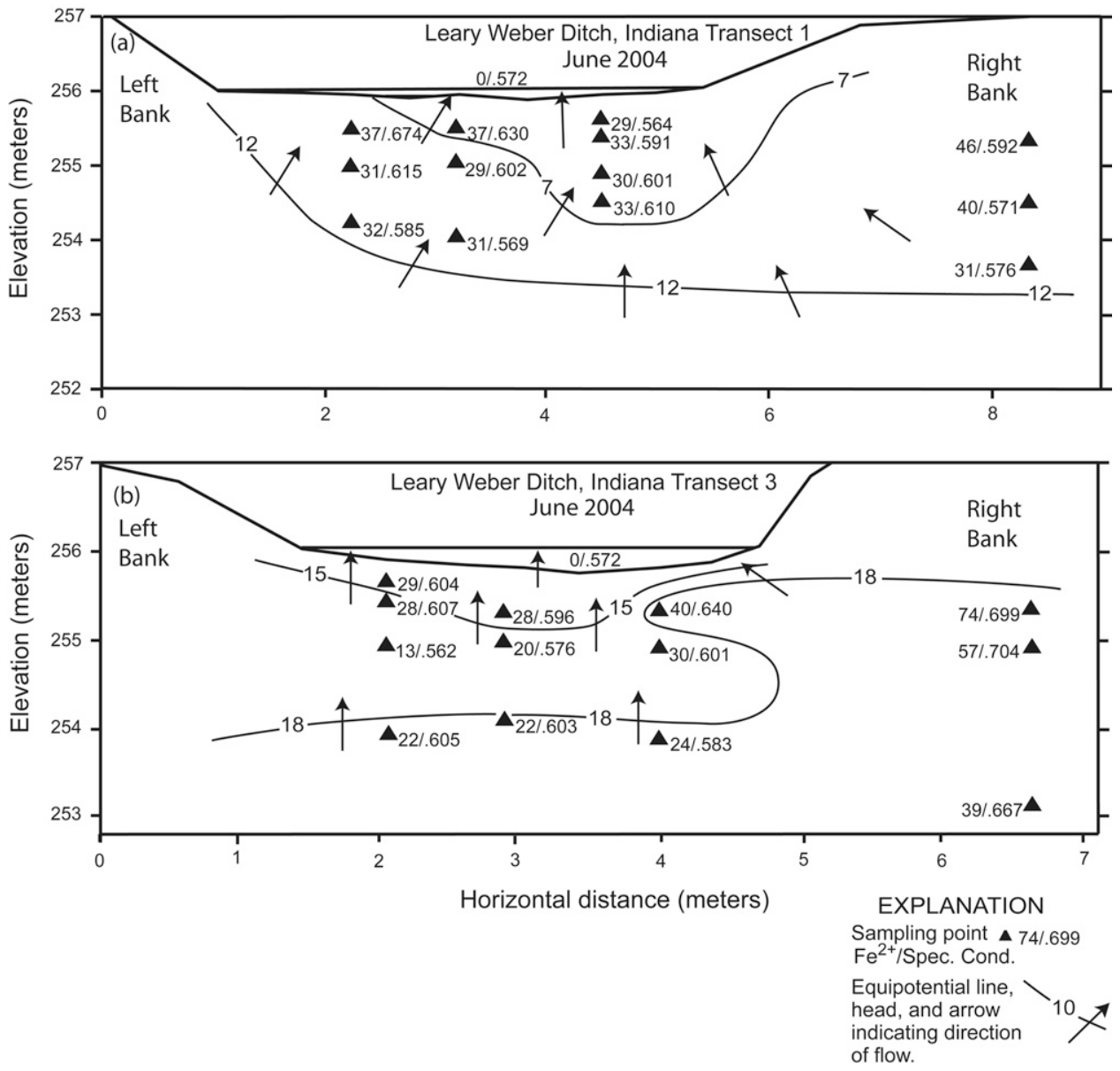

Fig. 8. Concentrations of $\mathrm{Fe}^{2+}\left(\mu \mathrm{mol} \mathrm{\textrm {L } ^ { - 1 } )}\right.$ and specific conductance $\left(\mathrm{dS} \mathrm{m}^{-1}\right)$ at the Indiana study site in June 2004 at (a) Transect 1 and (b) Transect 3. Equipotential lines and flow directions are based on potentiometric heads $(\mathrm{cm})$ measured at the time of sampling.

cation. Various researchers (Kölle et al., 1983; Strebel et al., 1985; van Beek et al., 1988; Postma et al., 1991; Böhlke and Denver, 1995; Tesoriero et al., 2000; Böhlke et al., 2002) have shown these processes to be important in various ground-water and riparian zone settings; however, the roles of these other potential electron donors in studies of denitrification in the hyporheic zone have generally been ignored.

The five sites examined in this study possessed varying amounts of potential electron donors required for denitrification in the form of organic carbon, reduced-iron phases, and sulfides (Fig. 12). Dissolved $\mathrm{O}_{2}$ concentrations at all sites were highly variable but well below equilibrium values, indicating oxygenconsuming reactions were taking place; all sites displayed a range of redox conditions in the streambed. Although the DR2 Drain site had the largest concentrations of available $\mathrm{Fe}^{2+}$, the Leary Weber Ditch site had large concentrations of several potential electron donors, including reduced-iron phases, sulfides, and organic carbon, and therefore had the greatest excess of potential electron donors. Consequently, the Leary Weber Ditch site had the strongest reducing conditions among the sites.

Nitrogen isotope and $\mathrm{N}_{2 \text {,denit }}$ data indicate that denitrification contributed to decreases in $\mathrm{NO}_{3}{ }^{-}$concentrations in the streambed at the DR2 Drain, Merced River, and Maple Creek sites. At Leary 

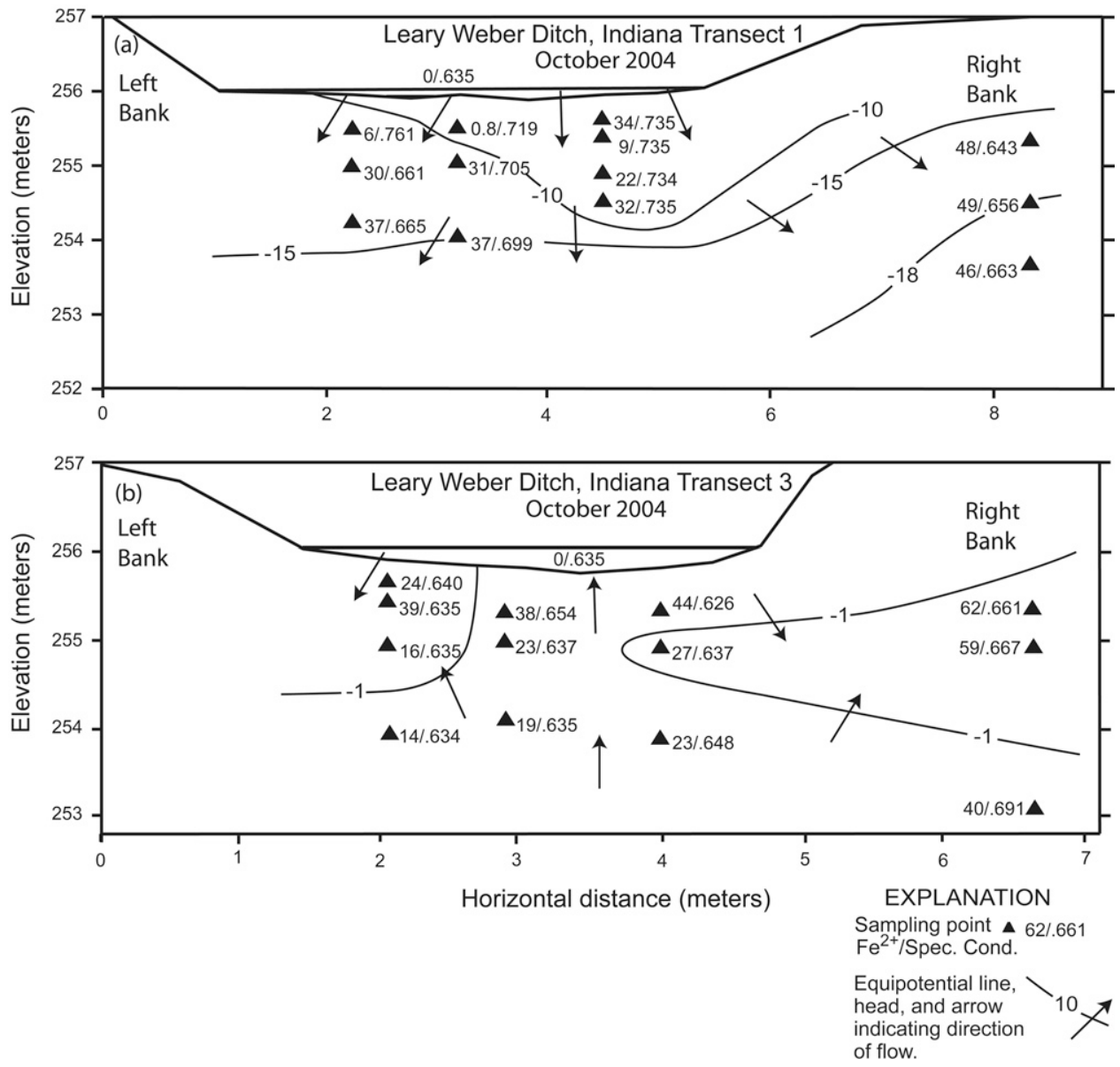

Fig. 9. Concentrations of $\mathrm{Fe}^{2+}\left(\mu \mathrm{mol} \mathrm{L} \mathrm{L}^{-1}\right)$ and specific conductance $\left(\mathrm{dS} \mathrm{m}^{-1}\right)$ at the Indiana study site in October 2004 at (a) Transect 1 and (b) Transect 3. Equipotential lines and flow directions are based on potentiometric heads $(\mathrm{cm})$ measured at the time of sampling.

Weber Ditch, the ground-water system in the riparian floodplain was dominated by iron-reducing conditions, and all $\mathrm{NO}_{3}{ }^{-}$in ground water had already been reduced before reaching the streambed. Consequently, at Leary Weber Ditch, only $\mathrm{NO}_{3}^{-}$entering the streambed in infiltrating surface water was available for denitrification, and $\mathrm{NO}_{3}{ }^{-}$was not present at depths greater than about $1 \mathrm{~m}$. Morgan Creek represented a unique set of conditions among the sites, yet even there $\mathrm{NO}_{3}{ }^{-}$concentrations were lower in the seep channels than in the discharging ground water, probably as a result of plant uptake and denitrification in the surface sediments, which contained the largest amounts of solid organic carbon measured. In among-site comparisons, denitrification reaction progress was most highly correlated with DOC (Kendall $\tau=0.74$ ), indicating that DOC probably was the most important electron donor for denitrification. The correlation with $\mathrm{Fe}^{2+}$ (Kendall $\tau=0.53$ ), however, indicates that it also was a likely electron donor in the denitrification process. Sediment organic carbon and $\mathrm{S}^{2-}$ concentrations seem to have been too small or unavailable among the sites to have consistently supported denitrification. These results are similar to those reported by Green et al. (2008) for the ground-water compartments of these same study sites.

Solid organic carbon content (Fig. 12) was low at most sites, but at the Merced River, Maple Creek, and Leary Weber Ditch sites, $\mathrm{DOC}$ was present at larger concentrations in pockets within bed sediments. Ammonium concentrations generally were below detection; however, at the Merced River and Maple Creek sites, median $\mathrm{NH}_{4}^{+}$concentrations of 4.5 and $2.4 \mu \mathrm{mol} \mathrm{L}^{-1}$, respectively, were detected where DOC concentrations were elevated above the median. At the Leary Weber Ditch site, the median $\mathrm{NH}_{4}^{+}$concentration of 3.3 $\mu \mathrm{mol} \mathrm{L}{ }^{-1}$ was virtually the same regardless of the DOC concentration; however, the lowest $\mathrm{DOC}$ value in Leary Weber Ditch $\left(117 \mu \mathrm{mol} \mathrm{L}^{-1}\right)$ was greater than the median values at Merced River $\left(108 \mu \mathrm{mol} \mathrm{L}^{-1}\right)$ and Maple Creek $\left(92 \mu \mathrm{mol} \mathrm{L}^{-1}\right)$, suggesting that a concentration of about $100 \mu \mathrm{mol} \mathrm{L}^{-1}$ was sufficient to support DNRA. These results indicate DNRA can account for only a small portion of $\mathrm{NO}_{3}{ }^{-}$losses at these three sites. As Tiedje et al. (1982) pointed out, denitrification is favored over DNRA because denitrification provides more energy, and DNRA is likely to occur only in settings where there is an excess of electrons donors such as at the Leary Weber Ditch site (Tiedje, 1988). Although DNRA was noted by Kelso et al. (1999) most researchers have not seen this process and it is assumed to be a minor factor in most stream settings (Duff and Triska, 2000). The generally limited availability of organic carbon and other electron donors at most of the study sites (Fig. 12) seems to support these previous observations and accounts for the correspondingly low $\mathrm{NH}_{4}^{+}$concentrations and the predominance of denitrification.

\section{Effects of Residence Time}

Triska et al. (1993) noted an inverse relation between $\mathrm{NO}_{3}$ concentration gradients and travel times of water passing through the hyporheic zone. Valett et al. (1996) proposed that N retention was a product of the rates and interactions of surface water and ground water and increased with residence time. Hill et al. (1998) did not see increased $\mathrm{NO}_{3}^{-}$retention as a result of longer residence times in hyporheic zones in their study streams and instead argued that pools and slow-moving stream sections allowed greater contact with streambed sediments, which increased $\mathrm{NO}_{3}^{-}$retention. More recently, Storey et al. (2004) reported that in spite of low denitrification rates, long residence times resulted in large cumulative $\mathrm{NO}_{3}{ }^{-}$retention. The residence time of water in the streambeds determined in this study also proved to be an important factor in the transport and fate of $\mathrm{NO}_{3}{ }^{-}$through the ground-water/surface- 


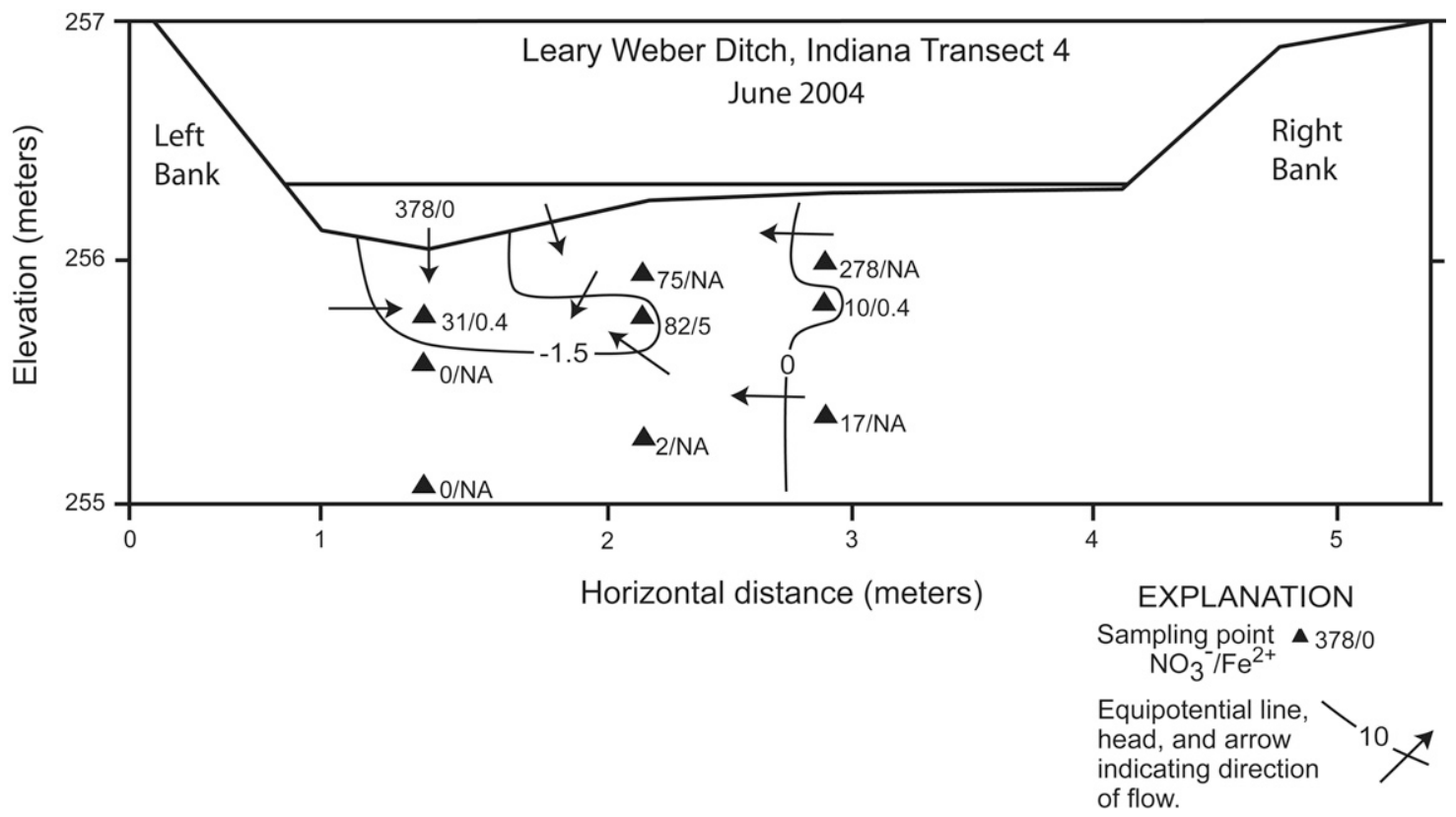

Fig. 10. Concentrations of $\mathrm{NO}_{3}{ }^{-}$and $\mathrm{Fe}^{2+}\left(\mu \mathrm{mol} \mathrm{L}^{-1}\right)$ at the Indiana study site in June 2004 at Transect 4. Equipotential lines and flow directions are based on potentiometric heads $(\mathrm{cm})$ measured at the time of sampling. NA, data not available.

water interface and was positively correlated (Kendall $\tau=0.53$ ) with denitrification reaction progress. In systems with fast transport rates, such as Maple Creek, which had a median residence time of $1.8 \mathrm{~d} \mathrm{~m}^{-1}, \mathrm{NO}_{3}^{-}$may move through the streambed faster than the biogeochemical processes that decrease $\mathrm{NO}_{3}{ }^{-}$concentrations can occur. The Morgan Creek site represents an extreme example of a hydrogeologic setting where a minimal amount of denitrification occurred as a result of inadequate redox controls and a short residence time $\left(0.28 \mathrm{~d} \mathrm{~m}^{-1}\right)$. At a site like the Merced River, which had the longest median residence time $\left(34.7 \mathrm{~d} \mathrm{~m}^{-1}\right)$, there was ample time for biogeochemical and physical processes to alter
$\mathrm{NO}_{3}{ }^{-}$concentrations in spite of relatively small amounts of potential electron donors. Given sufficient time, despite relatively small amounts of electron donors, denitrification can take place.

\section{Source-Sink Relations}

In the DR2 Drain site, $\mathrm{NO}_{3}{ }^{-}$in discharging ground water decreased at one transect but increased in another because of lateral influx of shallow ground water. The net result was a small but detectable increase of in-stream $\mathrm{NO}_{3}{ }^{-}$. At the Merced River site, concentrations of $\mathrm{NO}_{3}{ }^{-}$in ground water in the streambed also decreased, but on the basis of our results it is impossible to

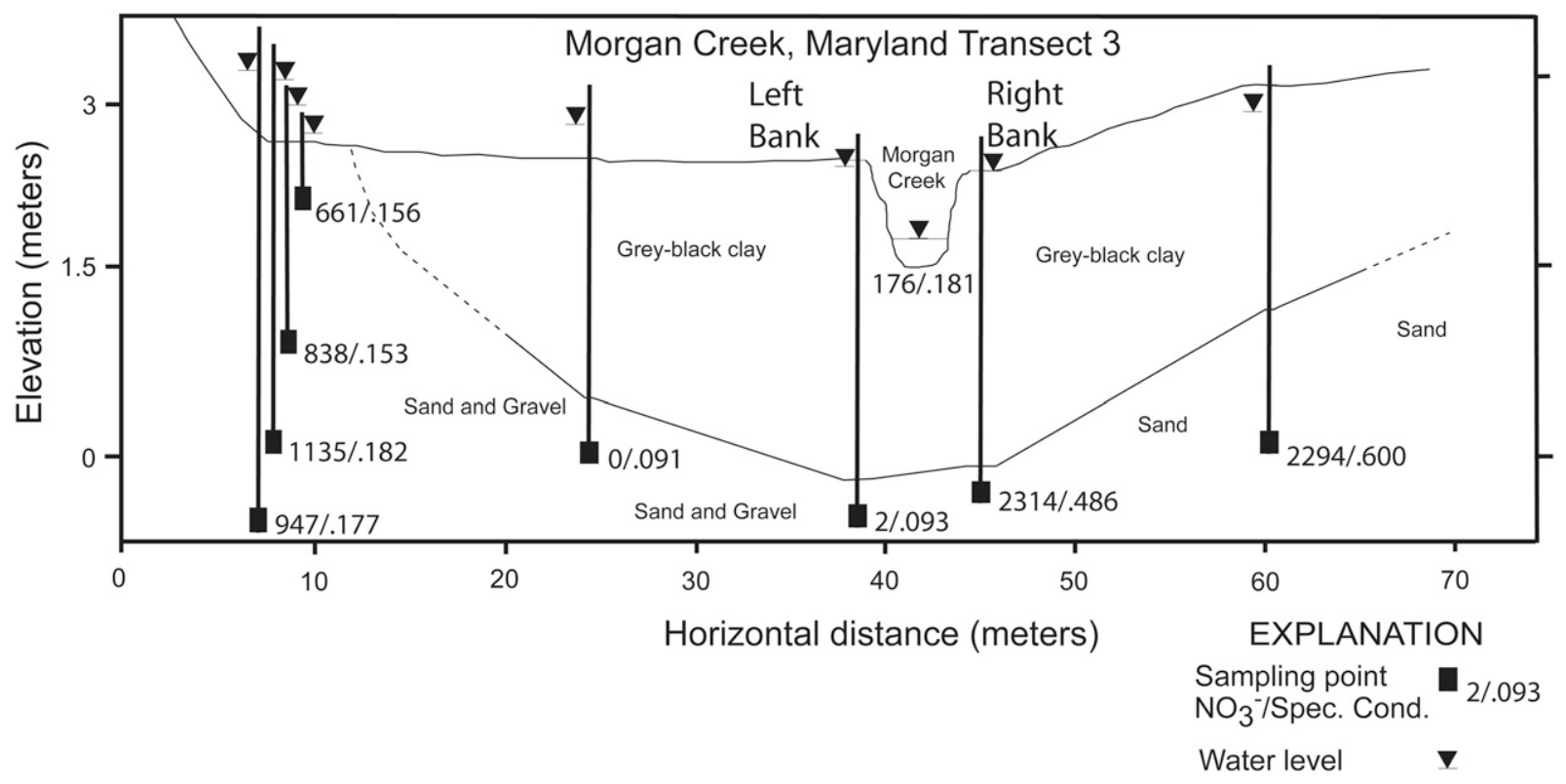

Fig. 11. Median concentrations of $\mathrm{NO}_{3}^{-}\left(\mu \mathrm{mol} \mathrm{L}{ }^{-1}\right)$, specific conductance $\left(\mathrm{dS} \mathrm{m}^{-1}\right)$, and water levels at the Maryland study site during 2004 at Transect 3. Water levels were measured at the time of sampling. 

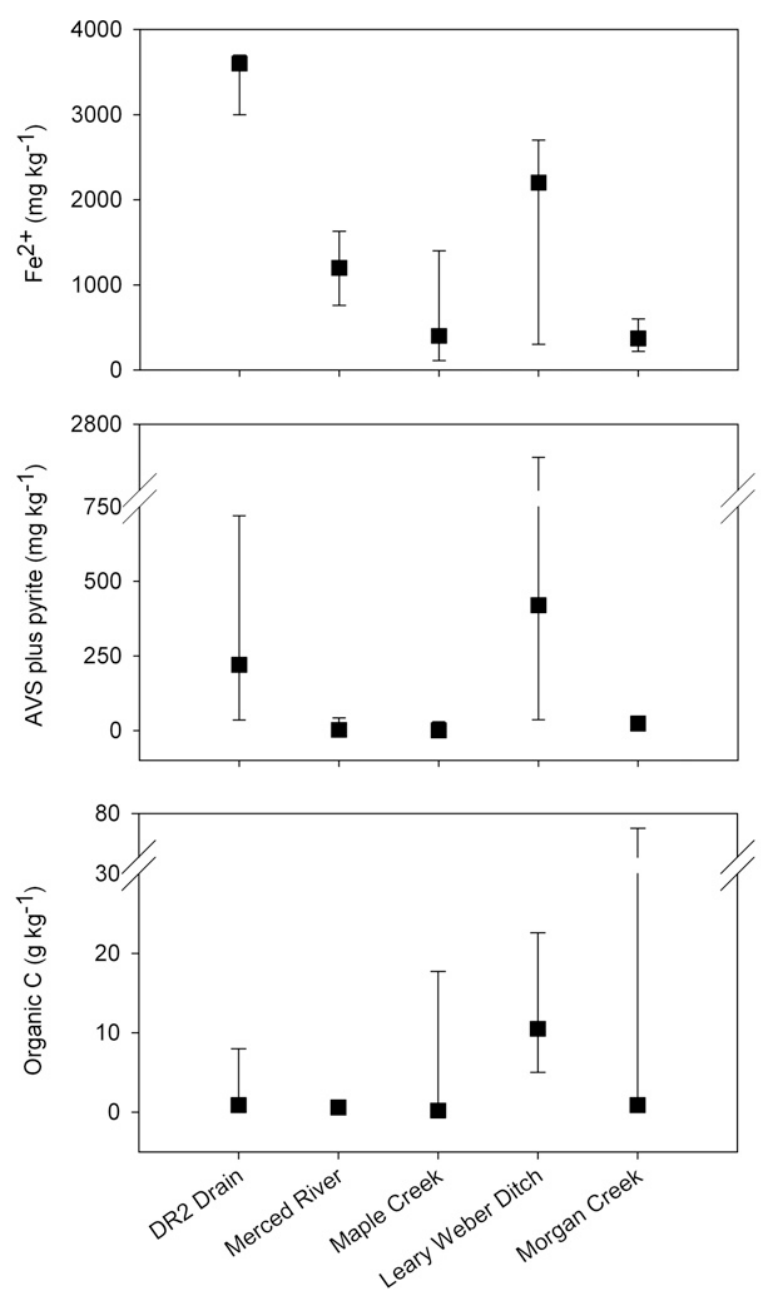

Fig. 12. Plots of $\mathrm{Fe}^{2+}$, acid-volatile sulfides plus pyrite $\left(\mathrm{mg} \mathrm{kg}^{-1}\right)$, and organic carbon concentrations $\left(\mathrm{g} \mathrm{kg}^{-1}\right)$ in the ground-water/surface-water interaction zones at the five study sites. Individual points are site medians, and error bars are minimum and maximum values.

say whether or not there was a net contribution of $\mathrm{NO}_{3}{ }^{-}$to surface water. At Maple Creek, although there was some decrease in $\mathrm{NO}_{3}^{-}$concentrations in ground water in the streambed, the remaining $\mathrm{NO}_{3}{ }^{-}$in combination with the large ground-water flux resulted in a net contribution to in-stream $\mathrm{NO}_{3}{ }^{-}$. Because there was no $\mathrm{NO}_{3}{ }^{-}$in the ground water at the Leary Weber Ditch site, there was no net loss or contribution to surface water; however, there was a net loss of $\mathrm{NO}_{3}{ }^{-}$from surface water at those locations and times when surface water infiltrated the streambed. Although there was no net loss of $\mathrm{NO}_{3}{ }^{-}$in the discharging ground water at Morgan Creek, concentrations in the seep channels were lower than in ground water but still elevated above those in the creek. Even though the water discharging to Morgan Creek had higher $\mathrm{NO}_{3}{ }^{-}$concentrations than in surface water, it was small in proportion to the volume of the creek; consequently, there was only a small net increase in $\mathrm{NO}_{3}{ }^{-}$concentrations in the creek.

At all of the study sites, $\mathrm{NO}_{3}{ }^{-}$concentrations in ground water decreased at some point before entering the stream, and in that context, each hydrogeologic setting provided an $\mathrm{NO}_{3}{ }_{3}^{-}$sink with respect to ground water. Even though $\mathrm{NO}_{3}{ }^{-}$decreased, it was not completely removed, and at three of the five sites (DR2 Drain, Maple Creek, and Morgan Creek), ground-water discharge contributed $\mathrm{NO}_{3}{ }^{-}$to surface water and was an $\mathrm{NO}_{3}{ }^{-}$source. At the remaining two sites (Merced River and Leary Weber Ditch), $\mathrm{NO}_{3}{ }^{-}$transported into the hyporheic zone in surface water decreased, with the hyporheic zone serving as an $\mathrm{NO}_{3}{ }^{-}$sink. In that respect, these results agree somewhat with the hypothesis of Jones and Holmes (1996) that hyporheic zones of N-rich streams act as $\mathrm{NO}_{3}{ }^{-}$sinks; our results indicate that, with respect to ground water, hyporheic zones also can act as $\mathrm{NO}_{3}{ }^{-}$sources. Our results also demonstrate that biogeochemical and hydrogeological processes in the streambed at most sites are capable of decreasing but not completely eliminating $\mathrm{NO}_{3}{ }^{-}$concentrations in ground water before they reach surface waters and therefore may serve as an added (but limited) bioremediation barrier to surface-water contamination.

These results also must be considered in relation to results reported by Hill et al. (1998) and Storey et al. (2004) that, because of limited movement of surface water through hyporheic zones, the amount of $\mathrm{NO}_{3}{ }^{-}$removed may be small relative to the stream load. Opdyke et al. (2006) and Royer et al. (2004; 2006) also indicated that in some systems the large flux of $\mathrm{NO}_{3}{ }^{-}$during high flow periods may so greatly exceed the denitrification capacity of the streambed that it is not an efficient $\mathrm{NO}_{3}{ }^{-}$sink. Consequently, even where $\mathrm{NO}_{3}{ }^{-}$is totally removed in streambeds, denitrification may not be sufficient to significantly reduce stream loads.

\section{Conclusions}

Analysis of a combination of physical and chemical data from five agricultural basins revealed that residence times of ground water in the streambeds of $\mathrm{N}$-rich watersheds played an important role in allowing denitrification to decrease $\mathrm{NO}_{3}^{-}$concentrations. Where potential electron donors were in limited supply, redox processes may be slower than ground-water flow rates, thereby limiting the degree of denitrification. Consequently, in spite of chemically reducing conditions in the streambed, $\mathrm{NO}_{3}^{-}$may be transported into the stream and contribute to surface-water $\mathrm{NO}_{3}{ }^{-}$loads. At two of the five study sites, $\mathrm{NO}_{3}{ }^{-}$in surface water infiltrated the streambeds and decreased in concentration, supporting current conceptual models of $\mathrm{NO}_{3}{ }^{-}$retention in $\mathrm{N}$-rich streams. At the other three study sites, hydrogeologic controls limited or prevented infiltration of surface water into the streambed, and ground-water discharge contributed to surface-water $\mathrm{NO}_{3}{ }^{-}$loads. These results demonstrate that although denitrification may not be complete, streambeds can decrease $\mathrm{NO}_{3}{ }^{-}$concentrations in ground water that bypasses riparian zones and serve as an $\mathrm{NO}_{3}^{-}$sink.

On the basis of the results described here, we propose a conceptual model of $\mathrm{NO}_{3}{ }^{-}$transport and fate in low-gradient, $\mathrm{N}$-rich streams that expands on previous models and incorporates the hydrogeologic and biogeochemical factors discussed previously. In this model, sediment characteristics determine the hydraulic conductivity and porosity of the bed sediments and therefore determine the potential for ground water and surface water to move through the streambed. The second hydraulic factor is the gradient between ground water and surface water. Where the surface-water gradient is greater, then surface water preferentially moves into the 
streambed; conversely, where the ground-water gradient is greater, then ground water preferentially moves into and through the streambed. This combination of factors determines the direction and rate of flow of water through the streambed and, inversely, the residence time. Nitrate retention in the streambed is determined by the relative abundance of electron donors to support denitrification or DNRA. Where residence times are shorter than the rate of biogeochemical processes, $\mathrm{NO}_{3}{ }^{-}$may pass through the streambed relatively unaltered. Conversely, even where the abundance of electron donors is relatively small, long residence times may allow slow biogeochemical processes to remove most or all $\mathrm{NO}_{3}{ }^{-}$before it discharges to surface waters.

This conceptual model is based on a limited range of studies and should be the subject of further studies in other hydrogeologic settings. More research is needed to better define the relative concentrations of electron donors necessary to support denitrification and DNRA. There is also a need to better define geomorphological and hydrogeologic controls, particularly residence times, as well as flow-dependent processes.

\section{Acknowledgments}

This study was conducted as part of the U.S. Geological Survey, National Water-Quality Assessment (NAWQA) Program, Agricultural Chemicals: Sources, Transport, and Fate study. We thank James LaBaugh, James Tesoriero, Chester Zenone, and three anonymous reviewers for their valuable comments on the manuscript. Any use of trade, product, or firm names in this paper is for descriptive purposes only and does not imply endorsement by the U.S. Government.

\section{References}

Allen, H.E., G. Fu, W. Boothman, D.M. Di Toro, and J.D. Mahony. 1991. Determination of acid volatile sulfide and selected simultaneously extractable metals in sediment. EPA 821-R-91-100. USEPA, Washington, DC.

Allen, H.E., G. Fu, and B. Deng. 1993. Analysis of acid-volatile sulfide (AVS) and simultaneously extracted metals (SEM) for the estimation of potential toxicity in aquatic sediments. Environ. Toxicol. Chem. 12:1441-1453.

Baker, N.T., W.W. Stone, J.T. Wilson, and M.T. Meyer. 2006. Occurrence and transport of agricultural chemicals in the Leary Weber Ditch Basin, Hancock County, Indiana, 2003-04, Scientific Investigations Rep. 2006-5251. USGS, Indianapolis, IN.

Blicher-Mathiesen, G., G.W. McCarty, and L.P. Nielsen. 1998. Denitrification and degassing in groundwater estimated from dinitrogen and argon. J. Hydrol. 208:16-24.

Böhlke, J.K., and J.M. Denver. 1995. Combined use of ground water dating, chemical, and isotopic analyses to resolve the history and fate of nitrate contamination in two agricultural watersheds, Atlantic coastal plain, Maryland. Water Resour. Res. 31:2319-2339.

Böhlke, J.K., R. Wanty, M. Tuttle, G. Delin, and M. Landon. 2002. Denitrification in the recharge area and discharge area of a transient agricultural nitrate plume in a glacial outwash sand aquifer, Minnesota. Water Resour. Res. 38, doi:10.1029/2001WR000663.

Bowles, K.C., M.J. Ernste, and J.R. Kramer. 2003. Trace sulfide determination in oxic freshwaters. Anal. Chim. Acta 477:113-124.

Canfield, D.E., R. Raiswell, J.T. Westrich, C.M. Reaves, and R.A. Berner. 1986. The use of chromium reduction in the analysis of reduced inorganic sulfur in sediments and shales. Chem. Geol. 54:149-155.

Capel, P.D., K.A. McCarthy, and J.E. Barbash. 2008. National, holistic, watershedscale approach to understand the sources, transport, and fate of agricultural chemicals. J. Environ. Qual. 37:983-993.

Domagalski, J.L., S.W. Ator, R.H. Coupe, K.A. McCarthy, D.C. Lampe, M.W. Sandstrom, and N.T. Baker. 2008. Comparative study of transport processes of nitrogen, phosphorus, and herbicides to streams in five agricultural basins, USA. J. Environ. Qual. 37:1158-1169.

Duff, J.H., A.J. Tesoriero, W.B. Richardson, E.A. Strauss, and M.D. Munn. 2006. Whole-stream response to nitrate loading in three streams draining agricultural landscapes in Yakima, Washington, Chestertown, Maryland, and Fremont, Nebraska. In Abstracts, Annu. Meet., Am. Soc. for Limnology and Oceanography, Victoria, B.C., Canada, 5-9 June 2006. Am. Soc. for Limnology and Oceanography, Waco, TX.

Duff, J.H., A.J. Tesoriero, W.B. Richardson, E.A. Strauss, and M.D. Munn. 2008. Whole stream response to nitrate loading in three streams draining agricultural landscapes. J. Environ. Qual. 37:1133-1144.

Duff, J.H., and F.J. Triska. 1990. Denitrification in sediments from the hyporheic zone adjacent to a small forested stream. Can. J. Fish. Aquat. Sci. 47:1140-1147.

Duff, J.H., and FJ. Triska. 2000. Nitrogen biogeochemistry and surface-subsurface exchange in streams. p. 197-220. In J.B. Jones and P.J. Muholland (ed.) Streams and ground waters. Academic Press, Boston.

Essaid, H.I., C.M. Zamora, K.A. McCarthy, J.R. Vogel, and J.T. Wilson. 2008. Using heat to characterize streambed water flux variability in four stream reaches. J. Environ. Qual. 37:1010-1023.

Findlay, S., and W.V. Sobczak. 1996. Variability in removal of dissolved organic carbon in hyporheic sediments. J. N. Am. Benthol. Soc. 15:35-41.

Fishman, M.J. 1993. Methods of analysis by the U.S. Geological Survey National Water Quality Laboratory—Determination of inorganic and organic constituents in water and fluvial sediments, USGS Open-File Rep. 93-125. USGS, Denver, CO.

Fishman, M.J., and L.C. Friedman (ed.). 1989. Methods for determination of inorganic substances in water and fluvial sediments. USGS Tech. of WaterResour. Invest. Book 5, chap. A1. U.S. Gov. Print. Office, Washington, DC.

Fredrick, B.S., J.I. Linard, and J.L. Carpenter. 2006. Environmental setting of Maple Creek Watershed, Nebraska. Scientific Investigations Rep. 2006-5037. USGS, Lincoln, NE.

Freeze, R.A., and J.A. Cherry. 1979. Groundwater. Prentice Hall, Upper Saddle River, NJ.

Fuhrer, G.J., R.J. Gilliom, P.A. Hamilton, J.L. Morace, L.H. Nowell, J.F. Rinella, J.D. Stoner, and D.A. Wentz. 1999. The quality of our Nation's Waters: Nutrients and pesticides. Circ. 1225. USGS, Reston, VA.

Green, C.T., L.J. Puckett, J.K. Böhlke, B.A. Bekins, S.P. Phillips, L.J. Kauffman, J.M. Denver, and H.M. Johnson. 2008. Limited occurrence of denitrification in four shallow aquifers in agricultural areas of the United States. J. Environ. Qual. 37:994-1009.

Gronberg, J.M., and C.R. Kratzer. 2006. Environmental setting of the Lower Merced River Basin, California. Scientific Investigations Rep. 2006-5152. USGS, Sacramento, CA.

Hancock, T.C., and M.J. Brayton. 2006. Environmental setting of the Morgan Creek Basin, Maryland, 2002-04. Open File Rep. 2006-1151. USGS, Baltimore, MD.

Harvey, J.W., and K.E. Bencala. 1993. The effect of streambed topography on surface-subsurface water exchange in mountain catchments. Water Resour. Res. 29:89-98.

Haycock, N.E., G. Pinay, and C. Walker. 1993. Nitrogen retention in river corridors: European perspectives. Ambio 22:340-346.

Heaton, T.H.E., and J.C. Vogel. 1981. "Excess air" in groundwater. J. Hydrol. 50:201-216

Hill, A.R. 1996. Nitrate removal in stream riparian zones. J. Environ. Qual. 22:743-755.

Hill, A.R., C.F. Labadia, and K. Sanmugadas. 1998. Hyporheic zone hydrology and nitrogen dynamics in relation to the streambed topography of a $\mathrm{N}$-rich stream. Biogeochemistry 42:285-310.

Hill, A.R., and D.J. Lymburner. 1998. Hyporheic zone chemistry and streamsubsurface exchange in two groundwater-fed streams. Can. J. Fish. Aquat. Sci. 55:495-506

Hinkle, S.R., J.H. Duff, F.J. Triska, A. Laenen, E.B. Gates, K.E. Bencala, D.A Wentz, and S.R. Silva. 2001. Linking hyporheic flow and nitrogen cycling near the Willametter River-A large river in Oregon, USA. J. Hydrol. 244:157-180.

Holmes, R.M., J.B. Jones, S.G. Fisher, and N.B. Grimm. 1996. Denitrification in a nitrogen-limited stream ecosystem. Biogeochemistry 33:125-146.

Jones, J.B., and R.M. Holmes. 1996. Surface-subsurface interactions in stream ecosystems. Trends Ecol. Evol. 11:239-242.

Kelso, B.H.L., R.V. Smith, and R.J. Laughlin. 1999. Effects of carbon substrate on nitrite accumulation in freshwater sediments. Appl. Environ. Microbiol. 
65:61-66.

Kölle, W., P. Werner, O. Strebel, and J. Böttcher. 1983. Denitrifikation in einem reduzierenden grundwasserleiter. Vom Wasser 61:125-147.

Korom, S.F. 1992. Natural denitrification in the saturated zone: A review. Water Resour. Res. 28:1657-1668.

Lovley, D.R., and E.J.P. Phillips. 1987. Rapid assay for microbially reducible ferric iron in aquatic sediments. Appl. Environ. Microbiol. 53:1536-1540.

McMahon, P.B., and J.K. Böhlke. 1996. Denitrification and mixing in a streamaquifer system: Effects on nitrate loading to surface water. J. Hydrol. 186:105-128.

McMahon, P.B., and F.H. Chapelle. 2008. Redox processes and the water quality of selected principal aquifer systems of the United States. Ground Water (in press).

Opdyke, M.R., M.B. David, and B.L. Rhoads. 2006. Influence of geomorphological variability in channel characteristics on sediment denitrification in agricultural streams. J. Environ. Qual. 35:2103-2112.

Owens, J.P., and C.S. Denny. 1979. Upper Cenozoic deposits of the central Delmarva Peninsula, Maryland and Delaware. Professional Paper 1067-A. USGS, Reston, VA.

Owens, J.P., and J.P. Minard. 1979. Upper Cenozoic sediments of the lower Delaware Valley and the northern Delmarva Peninsula, New Jersey, Pennsylvania, Delaware, and Maryland. Professional Paper 1067-D. USGS, Reston, VA.

Paschke, S.S., L.J. Kauffman, S.M. Eberts, and S.R. Hinkle. 2007. Overview of regional studies of the transport of anthropogenic and natural contaminants to public supply wells. Section 1. In S.S. Paschke (ed.) Hydrogeologic settings and ground-water flow simulations for regional studies of the transport of anthropogenic and natural contaminants to public-supply wells-Studies begun in 2001. Professional Paper 1737-A. USGS, Denver, CO.

Payne, K.L., H.M. Johnson, and R.W. Black. 2007. Environmental setting of the Granger Drain and DR2 Basins, Washington, 2003-2004. Scientific Investigations Rep. 2007-102. USGS, Tacoma, WA.

Pinay, G., N.E. Haycock, C. Ruffinoni, and R.M. Holmes. 1994. The role of denitrification in nitrogen retention in river corridors. p. 107-116. In W.J. Mitsch (ed.) Global wetlands: Old world and new. Elsevier, Amsterdam.

Postma, D., C. Boesen, H. Kristiansen, and F. Larsen. 1991. Nitrate reduction in an unconfined aquifer: Water chemistry, reduction processes, and geochemical modeling. Water Resour. Res. 27:2027-2045.

Puckett, L.J. 2004. Hydrogeologic controls on the transport and fate of nitrate in ground water beneath riparian buffer zones: Results from thirteen studies across the United States. Water Sci. Technol. 49:47-53.

Puckett, L.J., T.K. Cowdery, P.B. McMahon, L.H. Tornes, and J.D. Stoner. 2002. Using chemical, hydrologic, and age dating analysis to delineate redox processes and flow paths in the riparian zone of a glacial outwash aquiferstream system. Water Resour. Res. 38, doi:10.1029/2001WR000396.

Puckett, L.J., and W.B. Hughes. 2005. Transport and fate of nitrate and pesticides: Hydrogeology and riparian zone processes. J. Environ. Qual. 34:2278-2292.

Révész, K., and H. Qi. 2006. Determination of the $\delta\left({ }^{15} \mathrm{~N} /{ }^{14} \mathrm{~N}\right)$ and $\delta\left({ }^{13} \mathrm{C} /{ }^{12} \mathrm{C}\right)$ of total $\mathrm{N}$ and $\mathrm{C}$ in solids: RSIL Lab Code 1832, chap. C5. In K. Révész, and T.B. Coplen (ed.) Methods of the Reston Stable Isotope Laboratory: Reston, Virginia. Techniques and Methods, book 10, sec. C, chap. 5. USGS, Reston, VA. Available at http://pubs.water.usgs.gov/tm10C5/ (verified 24 Sept. 2007).

Royer, T.V., J.L. Tank, and M.B. David. 2004. Transport and fate of nitrate in headwater agricultural streams in Illinois. J. Environ. Qual. 33:1296-1304.

Royer, T.V., M.B. David, and L.E. Gentry. 2006. Timing of riverine export of nitrate and phosphorus from agricultural watersheds in Illinois: Implications for reducing nutrient loading to the Mississippi River. Environ. Sci. Technol. 40:4126-4131.

Sobczak, W.V., and S. Findlay. 2002. Variation in bioavailability of dissolved organic carbon among stream hyporheic flowpaths. Ecology 83:3194-3209.

Storey, R.G., D.D. Williams, and R.R. Fulthorpe. 2004. Nitrogen processing in the hyporheic zone of a pastoral stream. Biogeochemistry 69:285-313.

Strebel, O., J. Böttcher, and W. Kölle. 1985. Stoffbilanzen im grundwasser eines einzugsgebeites als hilfsmittel bei klarung und prognose von grundwasserqualitatsproblemen (Beispiel Fuhrberger Feld). Z. Dtsch. Geol. Ges. 136:533-541.

Tesoriero, A.J., H. Liebscher, and S.E. Cox. 2000. The mechanism and rate of denitrification in an agricultural watershed: Electron and mass balance along ground water flow paths. Water Resour. Res. 36:1545-1559.

Tiedje, J.M. 1988. Ecology of denitrification and dissilatory nitrate reduction to ammonium. p. 179-244. In A.J.B. Zehnder (ed.) Biology of anaerobic microorganisms. John Wiley \& Sons, Toronto.

Tiedje, J.M., A.J. Sexstone, D.D. Myrold, and J.A. Robinson. 1982. Ecological niches, competition, and survival. Antonie van Leeuwenhoek 48:569-583.

Triska, F.., J.H. Duff, and R.J. Avanzino. 1990. Influence of exchange flow between the channel and hyporheic zone on $\mathrm{NO}_{3}^{-}$production in a small mountain stream. Can. J. Fish. Aquat. Sci. 11:2099-2111.

Triska, F.J., J.H. Duff, and R.J. Avanzino. 1993. The role of water exchange between a stream channel and its hyporheic zone in nitrogen cycling at the terrestrial-aquatic interface. Hydrobiologia 251:167-184.

Triska, F.J., V.C. Kennedy, R.J. Avanzino, G.W. Zellweger, and K.E. Bencala. 1989. Retention and transport of nutrients in a third-order stream in northwestern California: Hyporheic processes. Ecology 70:1893-1905.

Tuttle, M.L., M.B. Goldhaber, and D.L. Williamson. 1986. An analytical scheme for determining forms of sulphur in oil shales and associated rocks. Talanta 33:953-961.

USEPA. 1996. Method 9030B: Acid-soluable and acid-insoluable sulfides: Distillation. Available at http://www.epa.gov/epaoswer/hazwaste/test/pdfs/ 9030b.pdf (verified 24 Sept. 2007).

USGS. 2007. Dissolved gas analysis. Available at http://water.usgs.gov/lab/ dissolved-gas/ (verified 24 Sept. 2007).

Valett, H.M., J.A. Morrice, and C.N. Dahm. 1996. Parent lithology, surfacegroundwater exchange, and nitrate retention in headwater streams. Limnol. Oceanogr. 41:333-345.

van Beek, C.G.E.M., H. Boukes, D. van Rijsbergen, and R. Straatman. 1988. The threat of the Netherlands waterworks by nitrate in the abstracted ground water, as demonstrated on the well field Vierlingsbeek. Water Supply 6:313-318.

Vervier, P., J. Gibert, P. Marmonier, and M. Dole-Olivier. 1992. A perspective on the permability of the surface freshwater-groundwater ecotone. J. N. Am. Benthol. Soc. 11:83-102.

Vogel, J.C., A.S. Talma, and T.H.E. Heaton. 1981. Gaseous nitrogen as evidence for denitrification in ground water. J. Hydrol. 50:191-200.

Waitt, R.B., Jr. 1984. Periodic jökulhlaups from Pleistocene glacial Lake MissoulaNew evidence from varved sediment in northern Idaho and Washington. Quat. Res. 22:46-58.

Weiss, R.F. 1970. The solubility of nitrogen, oxygen, and argon in water and seawater. Deep Sea Res. 17:721-735.

Wershaw, R.L., M.J. Fishman, R.R. Grabbe, and L.E. Lowe. 1987. Methods for the determination of organic substances in water and fluvial sediments. USGS Tech. of Water-Resour. Invest. Book 5. U.S. Gov. Print. Office, Washington, DC.

Winter, T.C., J.W. LaBaugh, and D.O. Rosenberry. 1988. The design and use of a hydraulic potentiomanometer for direct measurement of differences in hydraulic head between groundwater and surface water. Limnol. Oceanogr. 33:1209-1214.

Wondzell, S.M., and F.J. Swanson. 1996. Seasonal and storm dynamics of the hyporheic zone of a 4 th order mountain stream: II. Nitrogen cycling. J. N. Am. Benthol. Soc. 15:20-34. 